\title{
Sustainable of organic resources for bioenergy, food and water provision in rural Sub-Saharan Africa
}

\author{
Jo U. Smith ${ }^{a^{*}}$, Anke Fischer ${ }^{b}$, Paul D. Hallett ${ }^{a}$, Hilary Y. Homans ${ }^{c}$, Pete Smith ${ }^{a}$, \\ Yakubu Abdul-Salam ${ }^{\text {b }}$, Hanna H. Emmerling ${ }^{c}$, Euan Phimister ${ }^{d}$ \\ a University of Aberdeen, Institute of Biological and Environmental Sciences, School of Biological \\ Sciences, University of Aberdeen, 23 St Machar Drive, Room G45, Aberdeen, AB24 3UU, Scotland, \\ UK. Email address:jo.smith@abdn.ac.uk; paul.hallett@abdn.ac.uk; pete.smith@abdn.ac.uk. \\ b James Hutton Institute, Social, Economic and Geographical Sciences Group, James Hutton Institute, \\ Craigiebuckler, Aberdeen AB15 8QH, Scotland, UK. Email address: anke.fischer@hutton.ac.uk; \\ yakubu.salam@hutton.ac.uk \\ ${ }^{\circ}$ Centre for Sustainable International Development, MacRobert Building, 581 King Street, Aberdeen \\ AB24 5UD, Scotland UK. Email address: hilary.homans@abdn.ac.uk;
} hanna.emmerling.13@aberdeen.ac.uk.

${ }^{\mathrm{a}}$ Aberdeen Centre for Research in Energy Economics and Finance, Business School, University of Aberdeen, Aberdeen, AB24 3QY Scotland, UK. Email address: e.phimister@abdn.ac.uk.

* Corresponding author: Telephone: +44 1224 272702; Fax: +44 1224272703 E-mail: jo.smith@abdn.ac.uk.

ABSTRACT

This paper reviews use of organic resources in rural Sub-Saharan Africa (SSA), impacts on household energy, and interactions with provision of food and water. Wood, charcoal and dung supply over $70 \%$ of household energy in SSA, but with improvements in energy technologies, crop-residues and human excreta could also contribute. Improving cookstoves is not enough to make woodfuel use sustainable, reducing deforestation due to woodfuel demand by only $41-50 \%$. Further reductions of $21 \%$ are achieved by using crop-residues and $23 \%$ by anaerobic digestion of cattle manure. Taken together, these measures could reduce deforestation due to woodfuel demand by $70-100 \%$. Burning crop-residues loses a large proportion of nitrogen needed for crop production, which could be partially counteracted by applying biochar from pyrolysis cookstoves to improve retention of soil nitrogen. Better nutrient recycling would be achieved by composting, but this precludes energy provision. Both energy and efficient nutrient recycling are provided by anaerobic digestion, but carbon sequestration is reduced compared to composting or pyrolysis. Nevertheless, a wider range of waste materials may be recycled in the closed digester system, so pyrolysis of dry crop-residues together with anaerobic digestion of wet wastes is likely to provide the best solution for both food and energy. However, anaerobic digestion may demand more water than pyrolysis and, if soil carbon is reduced, may also increase the need for irrigation. Therefore, in water limited areas, biogas digesters should only be installed if integrated with water harvesting systems. Governments can encourage adoption of sustainable technologies by providing subsidies to cover fixed costs, facilitating credit and complementary infrastructure investments, and improving standardization and quality control in cookstove and digester markets. Implementation work should involve communities and households, giving women a role in decision-making to ensure community investment in water access.

Keywords:

Biogas; Pyrolysis; Composting; People-centered discourse approaches; Local and national governance; Sustainable organic waste practices

Abbreviations:

$\mathrm{SSA}=$ Sub-Saharan Africa 


\section{Introduction}

\subsection{Problem statement}

This paper considers the use of organic resources in rural areas of Sub-Saharan Africa (SSA), their impact on basic human requirements for energy, food and water, and how organic resource use can be made more sustainable. Organic "wastes", include crop-residues, food waste and excreta, and are of such value that many authors refer to them as organic "resources". Here we refer to residues from other processes as "organic wastes", and distinguish them from organic resources that have been grown or collected specifically for their primary use. This distinction is important, as it means that organic wastes represent a pool of resources that might not otherwise be used. Finding new ways of using them can help deliver the Millennium Development goals relating to poverty alleviation and environmental sustainability by extending access to clean energy and water and increasing sustainable agricultural production.

Globally, over 2.8 billion people still rely on unsustainable solid biomass for cooking and heating fuel, of which $\sim 2.2$ billion (78\%) live in rural areas. Communities in isolated rural areas often represent the poorest segment of the population in developing countries [1]. In countries without access to fossil fuels, organic resources provide a key source of energy. Wood, charcoal and dung are traditional biomass fuels that supply over $70 \%$ of the household energy in SSA [2]. Organic wastes provide alternative energy sources for cooking and lighting, either by direct burning of dried materials, or by anaerobic digestion to provide biogas [3].

The use of organic resources for energy directly impacts food production. Woodfuel use can cause localised deforestation, making more land available for agricultural production, but can also result in long-term loss of soil fertility and reduction in local rainfall [4]. Burning organic wastes removes carbon and nutrients from the agronomic system, whereas the residues from anaerobic digestion are rich in available nutrients, so providing farmers with a valuable organic fertiliser that can be used to improve yields $[5,6]$.

Organic resource use also affects water availability. Water quality can be improved by using organic wastes in energy production, so removing pathogens from the wider environment [7]. Burning of organic resources requires no extra water, whereas anaerobic digestion requires extra water to mix wastes into a slurry, and so impacts the quantity of water required by a household each day [3].

The best technical use of organic wastes depends on the availability of resources and requirements for food, energy and water, but there are also economic, social and cultural factors affecting adoption. At household level, organic waste practices, such as the purchase and use of a biogas digester, implies a range of changes; new capital expenditure may increase credit demand and change the household exposure to risk, but reduced expenditure on fuel may reduce weekly outgoings [8]. Social and gender relations within households and communities can also be affected; adoption of new technologies changes labour requirements for water and wood collection and for livestock management, so affecting both the total amount of labour and its allocation across family members [9].

In this paper, we consider the best technical use of organic wastes and how economic, social and cultural factors and social norms influence uptake. We examine the impact of adoption on agricultural productivity, energy provision and water use in poor rural households of SSA, and the role of social and economic forces. We review current policy issues and governance arrangements and consider what further changes are required to achieve sustainable solutions. Finally, we identify areas where evidence and understanding is lacking and prioritize future research goals.

\subsection{What are sustainable organic waste practices?}

Sustainability has been interpreted in different ways across and within disciplines. Within environment and development studies, sustainable development looks at the interaction between the economic, environmental and social spheres and how these impact on human development [10]. Within economics, definitions range from strong sustainability [11], where the need to conserve individual elements of natural capital are emphasised, to weak sustainability [12] where substitution of natural 
and other capital is emphasised and a sustainable environment merely maintains overall productive capacity. By this definition, strong sustainable organic waste practices require all dimensions of natural capital stock (forests, water and soil) to be conserved to provide a sustainable yield of wood, water and food for future users. By contrast, weak sustainable organic waste practices would allow degradation of individual resources if overall future production is maintained.

\subsection{International and national support for sustainable organic waste practices}

The potential environmental, health and economic benefits associated with sustainable organic resource use has led to a significant effort by governments in SSA, supported by national and international development agencies, to encourage rural households to adopt technologies that make better use of organic wastes.

At the international level there are several initiatives to improve energy use and introduce technologies to reduce deforestation and indoor air pollution. Two examples are the UN Sustainable Energy for All (SE4All) initiative [13] and the Global Alliance for Clean Cookstoves [14].

National Development Plans indicate the level of commitment by governments to introduce new technologies. Of the current National Development Plans in 46 countries in SSA, 16 make specific reference to "organic" fertilizers. The importance of safe disposal of household waste is mentioned in 36 national plans, with emphasis on hygiene and sanitation; some plans making specific reference to the absence of household toilet facilities. All plans (except for Equatorial Guinea) mention "water" and problems encountered in securing access to potable drinking water and, in some cases, the long distances women have to travel to obtain household water.

Many National Development Plans refer to the need to focus on renewable energy, with nine making specific reference to biogas production. For example, the Botswana National Development Plan 9 refers to the installation of household and commercial biogas digesters for cooking and electricity generation. A number of plans also place emphasis on decreasing wood use as an energy source e.g. Burkina Faso and Ethiopia.

The Africa Biogas Partnership Programme [15] aims to facilitate the construction of 100 thousand biogas plants in six countries in SSA by 2017. As a result, the number of biogas installations has grown significantly over the last few years; as of 21 September 2014, the number of digesters in Kenya was 12,837, and in Ethiopia and Tanzania was approaching 10,000 [15]. However, the overall success and uptake rate of the technology is significantly less in SSA than in Asia; for instance China had over 14 million small-scale digesters installed by the mid 2000s [16]. Furthermore, a number of biogas programmes have failed to achieve their potential, despite favourable physical and technical conditions. For example, support by SNV Netherlands Development Organisation for Senegal's programme to encourage small-scale biogas digester adoption has been withdrawn [17].

\section{Household energy provision}

Sustainable provision of household energy in SSA requires a sufficient supply of energy to remain available at a cost that is within the economic means of the household, and to be delivered in a way that does not have adverse health consequences. Wood, charcoal and dung are traditional fuels that supply over $70 \%$ of the household energy in SSA [2], but with improvements in energy technologies, crop-residues and human excreta also have potential to provide household energy (Table 1).

\section{INSERT TABLE 1}

\subsection{Option 1 - Cook on an open fire or unimproved cookstove}

Cooking with wood is widely done on an open or shielded fire [18], the most common forms of shielded fire being a three-stone fire or U-shaped mud cook-stove [19]. Cooking equipment and recipes have been adapted over generations to make use of energy provided in this way. Foods requiring long cooking times, such as the two hour steaming of matoke in Uganda, are particularly 
suited to cooking on a wood fire, and food cooked on wood has a distinctive flavour that is preferred by many people [20]. Therefore, people continue to use wood as a source of household energy, despite its many disadvantages.

Cooking on an open fire is very inefficient; Omer and Fadalla [21] reported cooking with firewood on an unimproved stove in Sudan had a thermal efficiency of only $17 \%$. Collection of firewood requires a significant input of time and energy. Firewood is usually collected by women and children [22], and this reduces time available for other important activities, such as childcare, education or paid work [23]. Cooking on a wood fire releases carbon monoxide and particulates at levels detrimental to human health [24], poor indoor air quality being linked to over 3.5 million premature deaths annually [25] and contributing to a wide range of child and adult diseases [26].

Despite these health risks, in areas of low population density and where forest regeneration is more rapid than collection of wood, woodfuel can be burnt as a sustainable source of household energy [4]. However, as the population increases, increased woodfuel collection and clearing of land for agriculture results in increased rates of deforestation, so increasing the burden of firewood collection on the household $[27,28]$, and woodfuel use becomes non-sustainable.

Globally, there is a very weak link between woodfuel demand and deforestation [29] because fire wood is often obtained from fallen wood or sources already felled for construction or land clearance [30]. By excluding these confounding factors, Subedi et al. [4] derived a relationship between deforestation and the amount of wood extracted from forests that could be applied in SSA with an uncertainty of $60 \%$. Of the deforestation observed in 2010 , they estimated that $70( \pm 42) \%$ can be attributed to woodfuel demand, rising to $83( \pm 50) \%$ by 2030 , largely due to increases in charcoal consumption.

Charcoal is an excellent cooking fuel; it has a higher energy density than wood, can be stored without insect problems, burns evenly and is easily extinguished and reheated [31]. Burning charcoal has a thermal efficiency of $28 \%$, compared to only $17 \%$ for woodfuel [22]. Charcoal is particularly favoured in urban applications, as the weight and volume needed for cooking is lower than woodfuel, allowing easier transport into towns [32]. However, when charcoal is burnt on a traditional cookstove, emissions of particulates of diameter less than $2.5 \mu \mathrm{m}$, which have greatest impact on respiratory health [33], are not significantly lower than for woodfuel, and carbon monoxide emissions are more than doubled [34]. The loss of energy during charcoal production means that 4-6 times more wood is needed to release the same amount of energy by burning charcoal than by direct burning of wood [31]. Therefore, increased charcoal use further increases the rate of deforestation; charcoal is less sustainable as a source of household energy than woodfuel.

Dried dung is also burnt to provide household energy in some countries [35]. It burns with a smouldering flame that is particularly suited to types of cooking such as injera baking in Ethiopia [36]. However, burning dung has a thermal efficiency of only $11 \%$, compared to $17 \%$ and $28 \%$ for wood and charcoal respectively [22]. Particulate emissions from burning dung are particularly toxic [37], and the preparation and drying of dung cakes requires significant labour input, usually by women [35]. Burning dung prevents carbon and nutrients from being returned to the soil, thereby reducing productivity of the land $[5,6]$. This reduces the number of animals a household can sustain, either due to pastures becoming nutrient depleted or due to less crops being grown to feed housed animals. Therefore, burning dung in itself reduces the amount of dung available for energy. In sparsely populated rural areas, animal production can be maintained by increasing the range of pastoral grazing, but with increasing population, the range of grazing becomes restricted, animal production per capita falls, and so the sources of dung for energy become more limited, and dung burning is no longer a sustainable energy source.

\subsection{Option 2 - Cook on an improved cookstove}

Improved cookstoves have been developed to reduce demand for wood and improve indoor air quality [38]. The first improved cookstoves allowed simultaneous cooking with multiple pots, included a chimney to remove smoke from the cooking area and a closed combustion chamber with adjustable metal dampers to regulate the air-fuel control system [19]. These cookstoves were easily cracked with repeated heating and cooling [39], or were made of non-locally available materials, requiring extra expenditure for maintenance and resulting in discontinuation of cookstove use over the long-term. 
Therefore, more recent developments have focussed on construction from locally available materials and easy maintenance to provide efficient, affordable and durable cookstoves [19].

Increasing efficiency of combustion requires improved mixing of oxygen and combustible gases, and better heat transfer. If air is supplied by natural draft, stove geometry and insulation dictates combustion efficiency, but this can also be improved in forced air stoves using a fan to increase mixing of combustible gases with oxygen. Forced air stoves decrease fuel consumption by $40 \%$ and emissions by $90 \%$ [40], but the introduction of a fan increases cost and maintenance issues.

A very successful natural draft stove, the Rocket stove [41], includes an insulated space around the fire using lightweight, heat resistant materials to reduce heat loss; an insulated short chimney above the fire to increase draft; a side flue and grate to maintain a fast draft through the burning fuel; and gaps between the flame and pot to maximise heat transfer. These Rocket-type stoves reduce fuel consumption compared to a three-stone fire by $33 \%$, carbon monoxide emissions by $75 \%$ and particulate emissions by $46 \%$ [40]. Further modifications include pot skirts [42], which reduce fuel consumption and carbon monoxide emissions by $25-30 \%$ [41].

Improved efficiency and emission reductions can also be achieved by micro-gasification, the basis of pyrolysis cookstoves [43]. This separates combustible gases from biomass through gasification and then burns these gases as the fuel. Laboratory measurements show this decreases average emissions of particulate matter by $90 \%$ [41]. Pyrolysis cookstoves allow use of dried crop-residues to supplement woodfuel, so reducing use of wood or dung for energy [44,45]. The thermal efficiency of pyrolysis is $38-50 \%$, depending on the quality of feedstock and reaction conditions [46]; this compares well to traditional burning of wood $(17 \%)$ charcoal $(28 \%)$ or dung (11\%) [21]. In a study of institutional kitchens in schools in Uganda, pyrolysis gasifier stoves saved over two thirds of the wood used in a traditional three-stone fire [47].

Pyrolysis cookstoves produce a hot flame, so new cooking methods and equipment may be needed to prepare traditional foods [48]. As a new technology that is not yet widely adopted, the cost of stoves can be elevated in some regions [48] and knowledge about usage may be limited [49]. Using crop-residues for fuel might prevent them being used for other purposes, such as animal feeds or for compost [50], but in a study in Vihiga, western Kenya, Torres-Rojas et al. [45] determined that only $25 \%$ of maize crop-residues were used for animal feed, the remaining $75 \%$ being available for pyrolysis. This provided more energy than the average per-capita energy consumption, and reduced wood energy consumption by $27 \%$.

Pyrolysis leaves a carbon-rich charred residue, known as biochar, which can either be incorporated into the soil as a soil improver [51,52,53] or further burnt as charcoal [49]. If crop production is improved by incorporating biochar, this could increase the availability of crop-residues for pyrolysis, making a pyrolysis cookstove a highly sustainable source of energy. However, the impact on crop production of incorporating biochar compared to other uses of organic wastes is highly soil dependent; long-term sustainability of using pyrolysis of crop-residues requires further study $[5,6]$.

Subedi et al. [4] estimated average woodfuel demand in countries of SSA when using unimproved cookstoves to be $21 \mathrm{Mt}^{-1}$. If the thermal efficiency of cookstoves is improved from $17 \%$ of a threestone fire [21] to $38-50 \%$ of a pyrolysis cookstove [43], the average demand for woodfuel would be reduced to 7-9 $\mathrm{Mt} \mathrm{y}^{-1}$ (Fig.1). According to Subedi's equation for deforestation, this would equate to a reduction in deforestation of an average of $41( \pm 25) \%$ to $50( \pm 30) \%$. Assuming a $27 \%$ reduction in woodfuel demand from using crop-residues as an alternative fuel source [45], this could reduce the average deforestation by $21( \pm 12) \%$.

\section{INSERT FIGURE 1}

\subsection{Option 3 - Cook using biogas}

Dung, human excreta, crop-residues and food waste can be used to provide household energy through anaerobic digestion to release biogas. The energy yield from anaerobic digestion is highly 
variable, depending on the conditions and composition of the feedstock [54], but the calorific value is typically $21-24 \mathrm{MJ} \mathrm{m}^{-3}$ [55], and thermal efficiency can be as high as $75 \%$ [56] compared to $38-50 \%$ for pyrolysis [47] and only $11 \%$ for burning dung [21]. The biogas produced is composed of $50-70 \%$ (by volume) methane, $25-40 \%$ (by volume) carbon dioxide and traces of hydrogen sulphide, water vapour and ammonia [57]. Emission of particulates and carbon monoxide are low, potentially reducing health risks from respiratory and cardiovascular diseases by $20-25 \%$ [58].

Subedi et al. (2014) [4] estimated that producing biogas from cattle dung alone could reduce national woodfuel demand by, on average, $21 \%$; this would be equivalent to a reduction in current deforestation due to woodfuel demand of $23( \pm 14) \%$ (Fig.2). Organic wastes are decomposed wet, which allows feedstocks to be used without drying, but requires approximately $20 \mathrm{dm}^{3}$ additional water for each $\mathrm{kg}$ of dry matter decomposed $[3,59,60]$, so in some parts of Africa, anaerobic digestion may not be viable without further investment in water harvesting equipment.

\section{INSERT FIGURE 2}

If biogas is produced from organic wastes that would otherwise be burnt or left to decompose, and the digester is maintained effectively over the long-term, it can provide a sustainable source of household energy. The residue from the digestion process, bioslurry, provides a valuable, nutrient rich organic fertiliser that can be applied directly to crops [61,62], so increasing availability of organic wastes for energy production and sustainably improving household energy production. However, long-term maintenance of digesters in SSA has been poor, with up to $50 \%$ no longer functioning after ten years due to inadequate maintenance and repair [63]. So, although biogas is, in theory, a sustainable source of household energy, unless support is provided for maintenance, it will not be sustained in the long-term.

\section{Impact on food provision}

Sustainable provision of food in SSA faces challenges of increasing population and changing climate. Agricultural soils are vulnerable to degradation because of rapid carbon turnover (3-5 times faster than temperate regions) and poor nutrient retention, so recycling of organic resources is essential to replenish carbon and plant nutrients $[64,65,66]$ and avoid adverse impacts on yield, water storage and erosion resistance [67]. Inorganic fertiliser use is beyond the reach of many households [68]. Whilst organic resource use for food or energy provision can present some conflicts, there are opportunities to produce secondary resources after fuel use that have lasting impacts on food production $[69,70]$ (Table 2).

\section{INSERT TABLE 2}

\subsection{Option 1 - Use residues for food production only}

In some areas of SSA, a tradition of incorporating fresh wastes into soils already exists [71]. However, fresh wastes, such as farmyard manure, can be highly heterogeneous, containing some carbon rich materials that tend to immobilise nutrients as well as other nutrient rich materials that tend to release nutrients too quickly for plant uptake, leaving them susceptible to loss [72]. Application of untreated organic wastes to agricultural land can also spread any pathogens present in the waste $[73,74]$ causing health problems from food contamination and pollution of water courses from runoff $[75,76]$.

Composting farmyard manure, slurry, food wastes and crop-residues homogenises organic wastes so that nutrients are released at a rate that can be efficiently used by crops [65]. Pathogen levels are also decreased, making wastes more suitable for direct application to agricultural land $[77,78]$. Composting results in loss of carbon and nutrients; Bernal et al. [79] reported losses of carbon during composting between 52 and 74\%, while Kirchmann and Widén [80] observed losses of nitrogen between 26 to $62 \%$, these losses being highly dependent on composting conditions [81]. 
Smith et al. [5] estimated the susceptibility of nutrients to loss when wastes are applied to soil. When applied as an untreated waste, $66 \%$ of the nitrogen available for crop growth was estimated to be susceptible to loss, whereas from matured compost, this was reduced to $22 \%$. By factoring in nitrogen losses during composting, maximum potential loss was 43-61\%, still significantly lower than from untreated waste $(66 \%)$. Whether this increased nitrogen loss occurs is dependent on rainfall and water holding capacity at the particular site. Composted wastes also contain more stabilised carbon than fresh waste, so are predicted to increase long-term carbon sequestration, even after losses during composting [6]. The impact of increasing carbon content on soil water and subsequent crop production is dependent on weather and soil conditions at each site. Further work is needed to identify regions where risk of nutrient and carbon loss is high if wastes are applied without pretreatment.

\subsection{Option 2 - Produce biogas for cooking and use the digestate to improve soils}

Composting prevents wastes from being used in energy provision as there is currently no easy way of capturing the heat energy released for use in cooking. Anaerobic digestion has the advantage of allowing organic wastes to be used to provide energy, while also producing an effective organic fertiliser, rich in available nutrients [61]. It converts nitrogen into an immediately available form, providing a quick response fertiliser that can be applied when crops show signs of deficiency [82]. Carbon losses during anaerobic digestion 69-80\% [83] compared to the slightly lower losses during composting of $52-74 \%$ [79]. However, the carbon compounds in bioslurry are less stable than in composts, so this results in lower carbon sequestration rates, more comparable to incorporation of fresh wastes [6]. Because the treatment process is not open to the environment, additional organic wastes, such as human excreta, can be added to the digester, potentially compensating for this lower rate of carbon sequestration [84]. Losses of nutrients tend to be significantly lower during anaerobic digestion (5-10\%) [83] than during composting (26-62\%) [80]. Therefore, with the same starting material, anaerobic digestion will retain 1.2 to 2.5 times more nitrogen in bioslurry than is retained in compost.

Significant reductions in pathogens during anaerobic digestion are predicted [7], but some organisms are likely to withstand treatment temperatures. These include pathogenic species of Clostridia, which can cause wound and gastrointestinal infections, and neurological illness. Soil itself can be used as a biologically active filter to remove pathogens from poorly treated organic residues [85]. More work is needed to determine the safety of materials following anaerobic digestion for use in food production. This is timely, as a survey across SSA has found treated human excreta to be the most commonly used soil conditioner [86].

\subsection{Option 3-Burn organic wastes and use residues to improve soils}

Application of the ash produced by burning organic wastes can benefit food production, primarily by neutralising the acid soils $[87,88]$ commonly found in SSA [89]. In Cote d'lvoire, ash from burning secondary vegetation was $59 \%$ as effective as lime at raising soil pH [90]; on a different soil in South Africa, leaf litter derived ash was only $12 \%$ as effective [91]. Ash contains a range of nutrients, particularly phosphorus, potassium and magnesium. The nutrient content is dependent on feedstock, animal manures producing ash with greater nutrient content than crop-residues [92]. People in SSA commonly mix ash with fresh residues as a soil amendment [93]. Local knowledge, modern chemistry and recently released soil property maps [94] provide great potential to optimise mixtures for particular localities, soils and crops.

When organic wastes are burnt in the absence of oxygen, high temperature carbonization (pyrolysis) produces biochar, the quality depending on the feedstock and pyrolysis temperature. Biochar surfaces provide charged sites that adsorb nutrients and reduce leaching losses [95]. A high proportion of the nutrients in the organic waste can be volatilised during pyrolysis; Rovira et al. [96] report 70 to $90 \%$ of nitrogen is lost during pyrolysis. This means that pyrolysis retains 0.1 to 0.8 times as much nitrogen in biochar as is in composts, and only 0.1 to 0.3 times as much as is in bioslurry. However, the surface exchange sites of biochar might partially counteract this by reducing nutrient losses directly from the soil; in a soil that is deficient in surface exchange sites, this can significantly improve crop production by retaining more nutrients for uptake by crops [97]. 
A proportion of the carbon in biochar may be highly stabilised $[98,99]$, resulting in a long-term increase in the carbon content of soils [6]. This has been demonstrated to have an impact on productivity in some soils [100], although in severely nutrient limited soils, nutrient loss during treatment can produce lower yields compared to treatments that retain nutrients, such as anaerobic digestion or composting. Biochar may present risks from contaminants such as naphthalene that can be produced during pyrolysis [95]. However, this usually occurs at much higher temperatures than are present in the pyrolysis cookstoves adopted in SSA.

\section{Impact on water provision}

Use of organic wastes for household energy provision can impact the sustainable provision of water both in the quality of available water and the quantity of water required. With population growth and erratic rainfall patterns, provision of clean water becomes increasingly challenging. In a review of over 60 studies, Esrey et al. [101] found the largest impacts on morbidity-related diarrhoea come from increased water availability (25\%), better disposal of excreta (22\%) and improved water quality (16\%). Untreated organic wastes represent a significant source of pathogens and nutrient pollutants in drinking water [102]. By treating organic wastes, either by burning, composting or anaerobic digestion, these risks are significantly decreased, and by incorporating the resulting processed material into soils, drought resistance of crops can be improved (Table 3).

\section{INSERT TABLE 3}

\subsection{Option 1 - Burn organic wastes}

Burning or pyrolysis of organic wastes is an easy way to reduce pathogens in the environment and reduce the volume of waste materials. However, feedstocks for burning need to be dry [40], so at household level, dry crop-residues that have an inherently low pathogen risk tend to be the main feedstock. Dried animal manure can also provide a viable feedstock [34], and when the ash is used as a soil amendment it offers greater nutrient inputs than ash produced from crop-residues [92]. Burning other household wastes is widely practiced outside the home to reduce volume of waste materials. Burning of human sewage is mainly restricted to larger scale municipal applications.

\subsection{Option 2 - Bury organic wastes}

In rural areas, human faeces are often disposed of using pit latrines which are regularly back-filled and moved or emptied [103]. As the population increases, runoff from pit latrines increases and can reduce the quality of water used for drinking and washing. Nyenje et al. [104] observed groundwater below an urban slum area in Kampala, Uganda, to be anoxic with high concentrations of chloride, bicarbonate and ammonium ions, indicating wastewater leachates from pit latrines. Using data from eight different countries, Esrey [105] concluded that the health benefits of improved water quality and quantity would be realised only with improved access to sanitation. This could be achieved by attaching latrines to an anaerobic digester or by lining and regular emptying of pit latrines with further treatment of wastes to ensure safe disposal.

\subsection{Option 3-Apply untreated wastes to soil}

Untreated wastes that are still abundant in pathogens are often applied directly to soils to improve fertility. Wastewater may also be applied for irrigation [106]. This increases the spread of pathogens, but does not always present a significant risk. Pathogenic organisms can decay rapidly in soil due to ultraviolet radiation and heat of sunlight. Keraita et al. [107] found that if irrigation ceases a few days before harvest and rainfall is minimal, the risk of faecal contamination in leafy vegetables in Ghana decreased to safe levels for human consumption. Although the effectiveness will vary between soils and climates, pathogens carried from waste materials by rainfall or irrigation may also degrade in soil, further reducing risk of groundwater and surface soil contamination [85]. The risks presented by application of untreated wastes to soils is dependent on the pathogen content and rate of application, so as the density of the population increases, pre-treatment of wastes before application to soils becomes more important. 


\subsection{Option 4 - Treat wastes to reduce pathogen content, leaving a residue that can be safely applied to the soil}

Treatment of organic wastes by composting or anaerobic digestion can be used to reduce pathogens and provide a valuable soil amendment, but is less effective at reducing pathogens than burning or pyrolysis [7,77]. Anaerobic digestion can be used to treat human excreta [108], although some anaerobic pathogens may withstand the digestion process, so sequential digestion and composting may be needed when bioslurry is applied to food crops.

Additional water is needed for the digestion process [59,60], so it may be unsuitable in areas where water is limited, but the actual impact on water use is also dependent on soil water storage and changes in the need to irrigate crops. Incorporated organic wastes interact with soil surfaces to create a structure that captures and stores water more readily [109,110]. Applying biochar is the most effective way of increasing the carbon content of SSA soils, where the turnover of more labile carbon results in rapid depletion [6]. Improved water retention in biochar treated soils may result from greater root and earthworm activity as well as the direct impact of biochar porosity on retaining water [111]. However, even at application rates of $40 \mathrm{t} \mathrm{ha}^{-1}$, a study in a relatively fertile soil found no impact of biochar on the storage of accessible water for plants [111]. The impacts are dependent on biochar feedstock and soil properties, so local research is needed to explore the potential effectiveness of biochar in improving soil water storage.

When comparing the impact of differently treated wastes on water provision, complex factors interact to determine the demand for water. The much higher nitrogen levels in compost and bioslurry provide valuable crop nutrients that also improve root vigour and depth, so crops may be able to access water stored deeper in the soil profile [112]. With any soil amendment that improves soil carbon, the water use efficiency of the crop may also improve due to changes in soil structure. Crops in SSA have very low water use efficiency, with only $15 \%$ of rainwater being used by plants [113]. The rest is lost due to leaching through physically degraded soils. There is a surprising lack of data, however, to aid prediction of improved water infiltration and storage caused by the incorporation of organic wastes [114]. In a glasshouse study in Ghana, Adamtey et al. [115] found four times better water use efficiency for maize grown in soil treated with ammonia fertiliser and composted waste than in untreated soil. A field based study in Niger found similar improvements due to incorporation of a mulch [112].

\section{Encouraging sustainable organic waste practices}

\subsection{Why do households adopt sustainable organic waste practices?}

The benefits associated with sustainable use of organic wastes have led governments in SSA to encourage rural households to adopt technologies, such as small scale biogas digesters that are consistent with sustainable practices [116]. Despite some success, the rate of uptake of this technology is significantly lower in SSA than in Asia [8,117]. In this section we explore which factors appear important in the uptake of small scale biogas digesters, a key sustainable organic waste technology.

The simple economic approach to determine whether households adopt new technologies considers whether benefits outweigh costs [118]. A biogas digester generates a range of potential benefits, including improved health due to reduced smoke levels in cooking areas, savings on purchases of firewood for cooking and kerosene for lighting, a reduction in the time required to collect firewood and savings on purchases of inorganic fertilizer [119]. Costs include the capital cost of the digester, its installation and maintenance, costs of associated increases in water demand and labour tasks associated with digester operation [120].

If alternative employment opportunities are limited, adoption of biogas should be attractive to rural households. In a study covering Ethiopia, Rwanda and Uganda, Renwick et al. [121] suggested financial rates of return of $8-10 \%$. In Ugandan households with digesters, payback time based on reduced woodfuel, compost and fertilizer expenditures was estimated to be less than four years [122]; Walekhwa et al. [120] suggested simple payment periods as low as just over one year, with internal 
rates of return over $35 \%$. By comparison, studies on the financial returns to households who adopt biogas digesters in China suggest simple payback periods under two years [123]. This suggests that, if markets for biogas are operating effectively, the pace of adoption in SSA should be comparable to that in China and south-east (SE) Asian countries.

A number of factors may explain why this has not been the case. The financial benefits of adoption have been over-estimated in some cases. For example, in their ex-ante financial evaluation of the potential benefits to Rwandan households, Hubb and Paul [124] suggested financial payback periods of 1-2 years, while in the ex-post evaluation, based on actual expenditure in adopting households, reported payback was just under nine years [119].

Studies that have considered the economics of small scale biogas digesters have typically concentrated on changes in revenues and explicit costs, with the valuation of health benefits and extra labour costs relatively ignored. Freeing time associated with firewood collection is often identified as one of the major benefits to households [125]. For many traditional households across SSA, time spent collecting wood each day can be considerable $[125,126]$. The evidence for actual use of time when the household adopts a biogas digester is mixed. In their Ugandan study, Smith et al. [122] identified an average saving of 22 minutes a day for wood collection, but an increase of 34 minutes to collect water, while cooking and time required for collecting, preparing and loading the organic material in the digester meant that the overall time requirements within the household increased by 78 minutes per day. By contrast, Bedi et al. [119] identified a significant fall in time spent cooking per day, although water collection time, and time needed to process the organic material, increased.

Studies which value all household benefits and costs provide mixed evidence. Renwick et al. [121] include time costs and health benefits in their evaluations, and show that the overall economic returns associated with adoption can be large. However, if health benefits are excluded, for some households the overall return can be negative. Smith et al. [122] also show that, once implicit labour costs are accounted for, they dominate the financial benefits to the household.

Even within this simple economic framework, when benefits outweigh costs, households may not adopt the technology due to various market failures. Capital costs for biogas digesters have tended to be higher in SSA than in many SE Asian countries $[8,122,119,127]$. The installation costs are also high relative to median incomes in SSA. For the smallest size of fixed dome digester in the Rwandan Biogas Programme, the initial cost was around 1.4 times the average annual per-adult equivalent expenditure for the average household [128]. The high relative cost reflects the less well established biogas industry in countries of SSA. As new industries develop, costs tend to fall because the supply chain develops through "learning by doing" and existing technologies are adapted to use locally available resources; there is some evidence that costs may have already fallen in this way in SSA $[129,130,131]$.

As in all developing countries, access to credit is restricted for a large number of individuals. This has been identified as a barrier to adoption of sustainable energy technologies [132]. In many SE Asian countries, credit is widely used to finance biogas schemes [125]. By contrast, in Rwanda, less than $30 \%$ of successful applicants used credit to finance digester purchase [119]. Micro-credit and revolving saving schemes to enable poor households to cover the initial costs of digesters have been suggested as methods to address credit access issues for biogas adoption [119,128,133].

The size of subsidy granted by national governments determines the initial cost of biogas systems to households, and is therefore important in encouraging uptake of the technology. In China, widespread and rapid adoption was supported by a relatively high level of subsidy [134], although evidence of the importance is mixed [135]. Risk can also play a key role in household decisions. As new markets develop, consumers also tend to be uncertain about the costs and benefits of new products. There is evidence that both uncertainty in the benefits and failures in the reliability of systems have played a part in impeding adoption rates in SSA [68].

\subsection{Who decides and who benefits?}

In rural households, women's traditional roles of cooking, childcare, water and fuel collection mean that they are seen as the immediate beneficiaries from adoption of clean cooking and biogas digester 
systems. Women are primarily responsible for cooking in traditional households, so would be expected to benefit most from the reduction in smoke from wood burning within the home [136]. Women tend to work longer hours and have a wider range of tasks than men, so reductions in cooking time or wood collection (but increases in water collection) should have more impact on women $[9,35]$. By contrast, the new tasks needed for digester operation are often associated with livestock management, traditionally seen as the male domain [137].

The economic theory of the household, which considers within-household decision making, shows that women's bargaining power is a key factor in determining outcomes [138]. The extent that women influence biogas digester adoption decisions and benefit from them is likely to be complicated and context specific. Men typically remain the principal decision makers both within the household and in broader communities [9]. Within the household, men often have the most important role in purchasing decisions and this may inhibit adoption [139]. Nyoni [140] provides evidence from Zimbawe of men refusing to adopt solar cookers because of the impact on women's traditional roles. Clancy et al. [9] also argue that, even where women play a role in decision-making, they may undervalue their own welfare.

Even where a new technology is adopted, how the benefits are distributed in the household is not predetermined. In India, the adoption of clean cooking did not reduce time spent on wood collection by women, although there was a reduction for men [137]. Clancy et al. [9] argue that impacts of adoption on women depend on the wider economic context and the gender relations within the household. They cite evidence from rural China where the time savings for women associated with electrification were associated with migration of men to cities, increasing the burden on women due to increased responsibility for agricultural tasks [141]. Elsewhere, time saving for women was used either for new income generating activities, or to allow them to fulfil other traditional tasks [142].

Clancy et al. [9] also emphasise the need to consider the wider potential impact of modern energy services both within the household on gender relations and for wider norms and values within the communities in which individuals live. For example, concern has been expressed that a lack of women's involvement at village and higher level decision making may undervalue their time [143,144], and that infrastructure investments, such as improving and maintaining access to water, may have a lower priority as a result.

\subsection{Does local governance matter?}

In-depth empirical insights into the role of governance on the success of technologies are scarce. The studies that do exist, however, suggest the way schemes are implemented is important for their success. Troncoso et al. [145] studied the success of efficient cookstoves, introduced using very different approaches. They distinguished a "technology-centred" from a "people-centred" approach, and suggested that approaches differed in effectiveness, depending on stage of introduction of cookstoves. In their analysis of factors affecting adoption of improved biomass stoves, Barnes et al. [146] identified several relevant attributes of local governance of the implementation scheme. These included the role of local governments, of local artisans in the design of the stoves, and the influence of subsidies on adoption. In other, related areas, for example in research on the effectiveness of nature conservation interventions, local community involvement in decision-making has been shown to be important for project success [147].

\subsection{Encouraging local sustainable organic waste practices - different perspectives}

Alternative ways to investigate uptake of sustainable organic waste technologies can be found outside the bioenergy debate, for example, in development studies, where a body of literature exists about the need to involve communities and households in identifying acceptability, affordability, appropriateness, effectiveness and utility of new technologies to daily needs [148]. A strand of research in rural sociology and political ecology interprets trends in international development and environmental management in their discursive contexts. Discourses are understood as shared "ensembles of ideas, concepts and categories through which meaning is given to social and physical phenomena" [149]. We suggest here that it is useful to examine such shared ways of interpreting phenomena, as they can help explain why and how members of social groups react to the introduction of new technologies and ways of behaving (see examples in Fischer and Marshall [150]; Fischer et al. [151]). 
Adger et al. [152] and Svarstad et al. [153] distinguish between (a) managerial types of environmental discourse, expressing a faith in science and institutional solutions, in particular, in "win-win" approaches that are beneficial both economically and ecologically and (b) populist types of counterdiscourses that defend the rights of local people, and fend off interventions by external 'managerial' actors. Adger et al. [152] suggest that for most environmental issues, discourses of both types can be found, with the populist discourse often constituting a counter-narrative to the dominant managerial paradigm [154]. However, Adger et al. [152] also observe that both large-scale managerial and populist discourses influence policies that often do not correspond to the experiences of environmental change at the local level, due to their power as "knowledge regimes" or "shared myths and blueprints".

Elsewhere, researchers have explored elements of discourses implicit to the introduction of 'better' technologies and 'empowering' policies, such as in the context of community-based conservation programmes [155] or the provision of clean drinking water [156]. Instead of examining barriers to uptake from the intervening organisation's perspective, these authors take the viewpoint of the local residents who are the targets of the development intervention. In this way, Benjaminsen and Svarstad [155] show how modern discourses on community-based conservation, which are supposed to involve local residents in management and benefit sharing from natural resources, and thus create win-win situations for both conservation and the local economy, are often just a façade behind which the old 'fortress conservation' continues to exclude local populations from conservation areas.

Applied to sustainable organic waste use, such an approach can contribute to an understanding of the role and impacts of an intervention in its local context. If interventions to introduce sustainable organic waste practices are locally seen as a manifestation of a hegemonic managerial discourse that posits that environmental and economic challenges can be addressed simultaneously, it is of great importance to understand local reactions to such a discourse. The interpretation of environmental challenges as problems that need to be addressed within the context of energy, food and water provision could also be analysed from a discourse theoretical perspective, adding a strong reflexive component to the study that simultaneously examines the situation as well as the researchers' role in it.

\section{Conclusions}

Better use of organic wastes can make an important contribution to sustainable provision of energy, food and water to some of the poorest people in SSA. This paper emphasises that, for this potential to be realized, we need better recognition of three key points:

1. what is "best" is different in different locations and will use different combinations of technical solutions,

2. implied trade-offs between energy, food and water provision can also be very different,

3. "success", and who benefits, relies on complex interactions between what science makes possible and how decisions are made by individuals, communities and policy-makers.

Because the primary source of household energy in rural SSA is wood, deforestation due to wood fuel demand provides a useful measure of the sustainability of energy supply. Burning wood and charcoal increases deforestation, and burning dung decreases soil productivity, so a method that avoids burning, such as anaerobic digestion, would appear be a more sustainable way of providing household energy. However, anaerobic digestion is insufficient, on its own, to provide sustainable energy in rural SSA. A sustainable energy supply would require a combination of solutions, including improved cookstoves and digesters that use a much wider range of organic wastes. Anaerobic digestion of cattle manure would reduce average national deforestation due to woodfuel demand by $8-36 \%$, whereas improving cookstoves reduces deforestation by $41-50 \%$, with potential further reductions of $21 \%$ by burning crop-residues (Fig.3). Taken together, these measures could reduce deforestation due to woodfuel demand by an average of $70 \%$ to over $100 \%$, so go a long way towards providing sustainable household energy in rural SSA. 
The main factors limiting crop production in SSA are the supply of nutrients and water. The quality and quantity of soil organic matter control these factors, and so provide a useful measure of the sustainability of food production. The different uses of organic waste have different impacts on soil organic matter. They also embody quite different trade-offs between sustainable energy and crop production. Burning crop-residues removes from the system a large proportion of the nitrogen needed for crop production. Applying the biochar residue from pyrolysis cookstoves may partially counteract this by improving retention of the nitrogen that is already in the soil, but better recycling would be achieved by composting crop-residues. However, this precludes the use of organic wastes as an energy source. Anaerobic digestion provides both energy and efficient nutrient recycling, but carbon sequestration is reduced compared to composting and pyrolysis. Nevertheless, if a wider range of waste materials can be recycled due to the digester being a closed system, the carbon content of the soil may be comparable or even higher than with composted wastes. The additional plant inputs resulting from improved crop nutrition may further increase the carbon content of the soil following application of bioslurry. Therefore, pyrolysis of dry crop-residues together with anaerobic digestion of wet wastes is likely to provide the best improvements in food production while also improving energy provision.

Organic waste practices also impact differently on the quality and quantity of water available. In some cases there are difficult trade-offs to resolve between energy, food and water provision. Water quality is determined by the pathogen and nutrient content. Anaerobic digestion facilitates recycling of nutrients to the crops, but may not provide sufficient treatment of pathogens on its own. Sequential anaerobic digestion and composting may be needed to provide a more complete treatment of pathogens. The quantity of water used by a household is determined by water required for drinking, washing, cooking, cleaning and irrigation. Increasing the carbon content of the soil increases the water holding capacity, so decreasing the need for irrigation. Given the same initial amount of organic waste, treating it by anaerobic digestion will require more water for processing and, if the carbon content of the soil is reduced compared to composting or pyrolysis, may also increase the need for irrigation. Such effects could be mitigated if water used in anaerobic digestion is used to replace irrigation water. Nevertheless, in some areas, access to water will be prohibitive and so a biogas digester should only be installed as part of a system that is integrated with water harvesting equipment (Fig. 4).

\section{INSERT FIGURE 4}

A combination of anaerobic digestion with sequential composting and pyrolysis using improved cookstoves would appear to be the best use of organic wastes to improve energy, food and water provision in rural households in SSA. But is this a good option economically? How do these uses of organic wastes compare to other ways of generating household energy, providing nutrients to crops and improving water quality by waste treatment? The re-use of organic wastes is particularly attractive in under-resourced communities as it appears to make use of resources that are freely available, even in excess, to provide free energy, organic fertilizer and clean water. However, there are costs associated with the purchase of improved cookstoves and biogas digesters, especially if water harvesting equipment is also required. How do these costs compare to other ways of generating energy in rural areas of SSA? How do they compare to the costs of fertiliser? How do they compare with more centralised methods of water treatment? At the household level, payback times suggest that improved cookstoves and biogas digesters are economically viable, but at national level, policies to encourage investment in biogas are only viable if communities continue to make use of digesters over the long-term.

Simple cost versus benefit analyses suggest that successful uptake of more sustainable organic waste practices should be much higher than observed in practice. Why is this not the case? Are there key complementary inputs such as credit and water that are missing? Do the perceived risks associated with the technologies deter adoption? If so, government has an important role in facilitating (micro) credit and infrastructure investments, and encouraging greater standardization and quality control in the cookstove and digester market to reduce consumer uncertainty.

A broader perspective also suggests other important forces at play. At first glance, women are likely to benefit even more than men if sustainable organic waste practices are adopted. However, gender 
relations within households and the broader community play an important role in determining adoption decisions and deciding who ultimately benefits. Policy interventions need, therefore, to consider how they impact the distribution of labour and women's bargaining power within the household. For example should access to micro-credit for improving use of organic wastes focus on women, as in the original Grameen scheme [157]? How can the role of women in local decision-making be strengthened to ensure communities invest in complementary inputs such as water access?

Analysing the debate over sustainable organic waste practices from a discourse-theoretical perspective might also be helpful. From the perspective of rural people, interventions that aim to introduce novel practices for organic waste use can be perceived as manifestations of powerful, but alien, worldviews that impose new and potentially threatening ways of interpreting current practices, including key aspects of daily lives, such as food preparation and gender relations. Examining perceptions of these discourses, and the counter-discourses that arise during attempts to introduce new practices could help policy-makers design interventions that are more people-centred and therefore likely to be better adapted to the local context.

In future work, we need a better scientific understanding of the spatial distributions of forest, water and soil resources in SSA and their implications for wood, food and water availability as this provides the basic environment in which individuals, households and communities make their decisions. Likewise, better insights from social science are needed to explain the rate of adoption of more sustainable organic waste practices, as these will help determine what future technical research is likely to be productive. Time spent collecting woodfuel across SSA should be quantified to determine impact of reduced woodfuel demand on daily household labour. The impact of switching fuels on indoor air pollution and human health requires further analysis. Simulations and regional scale data should be used to derive maps of the potential for loss of nutrients, carbon sequestration and changes in water holding capacity when applying differently treated organic wastes. Simulations of access to water should be used to identify areas in SSA where water availability is likely to limit use of biogas. More work is needed to determine the safety for use in food production of differently treated materials. Finally, the impact of local and national governance and social organisation on adoption of sustainable organic waste practices requires further investigation.

\section{Acknowledgements}

We are grateful to the United Kingdom Economic and Social Research Council Nexus Network for funding this work. 


\section{Figures}

Figure 1. Potential reduction in woodfuel demand by introduction of pyrolysis cookstoves to replace unimproved cookstoves or open fires. Error bars represent the range of reduction depending on the efficiency of the cookstove (38-50\% [46]). Efficiency of unimproved cookstove assumed to be $17 \%$ [21]. Reduction in woodfuel demand due to replacement of wood by crop-residues assumed to be $27 \%$ [45]. Woodfuel demand for unimproved cookstoves derived by Subedi et al. [4] from data supplied by FAOSTAT [28].

Figure 2. Potential reduction in woodfuel demand by introduction of biogas stoves to replace unimproved cookstoves or open fires. Error bars represent the range of reduction depending on production of manure. A further $60 \%$ uncertainty is attributed to the prediction of deforestation [4]. Efficiency of a biogas cookstove assumed to be $75 \%$ [56]. Efficiency of unimproved cookstove assumed to be $17 \%$ [21]. Woodfuel demand for unimproved cookstoves derived by Subedi et al. [4] from data supplied by FAOSTAT [28].

Figure 3. Potential of available organic wastes to reduce deforestation due to woodfuel demand using anaerobic digestion and pyrolysis cookstoves. Error bars represent the range of reduction depending on the efficiency of the cookstove (38-50\% [46]) and production of manure [4]. A further $60 \%$ uncertainty is attributed to the prediction of deforestation [4]. Reduction in woodfuel demand due to replacement of wood by crop-residues assumed to be $27 \%$ [45]. Efficiency of a biogas cookstove assumed to be $75 \%$ [56]. Efficiency of unimproved cookstove assumed to be $17 \%$ [21]. Woodfuel demand for unimproved cookstoves derived by Subedi et al. [4] from data supplied by FAOSTAT [28].

Figure 4. Schematic for idealised design for latrine / biogas digester / water harvesting system 


\section{References}

[1] United Nations. Global conference on rural energy access: A nexus approach to Sustainable Development and Poverty Eradication. Economic Commission for Africa, Addis Ababa, Ethiopia, 4 to 6 December, 2013. Accessed in September 2014 at http://sustainabledevelopment.un.org/content/documents/2034energyaide3.pdf

[2] Sanbata H, Asfaw A, Kumie A. Indoor air pollution in slum neighbourhoods of Addis Ababa, Ethiopia. Atmos Environ 2014;89:230-4.

[3] Orskov B, Yongabi K, Subedi M, Smith J. Overview of holistic application of biogas for small scale farmers in Sub-Saharan Africa. Biomass Bioenerg 2014;70:4-16.

[4] Subedi M, Matthews R, Pogson M, Abegaz A, Balana B, Oyesiku-Blakemore J, et al. Can biogas digesters help to reduce deforestation in Africa? Biomass Bioenerg 2014;70:87-98.

[5] Smith J, Abegaz A, Matthews R, Subedi M, Orskov RE, Tumwesige V, et al. What is the potential for biogas digesters to improve soil fertility and crop production in Sub-Saharan Africa? Biomass Bioenerg 2014;70:58-72.

[6] Smith J, Abegaz A, Matthews R, Subedi M, Orskov RE, Tumwesige V, et al. What is the potential for biogas digesters to improve soil carbon sequestration in Sub-Saharan Africa? Comparison with other uses of organic residues, Biomass Bioenerg 2014;70:73-86.

[7] Avery LM, Yongabi K, Tumwesige V, Strachan N, Goude PJ. Potential for Pathogen reduction in anaerobic digestion and biogas generation in Sub-Saharan Africa. Biomass Bioenerg 2014;70:112-24.

[8] Mwirigi J, Balana B, Mugisha J, Walekhwa P, Melamu R, Nakami S, et al. Socio-economic hurdles to widespread adoption of small-scale biogas digesters in Sub-Saharan Africa: A review. Biomass Bioenerg 2014;70:17-25.

[9] Clancy J, Matinga M, Oparaocha S, Winther T. Social influences on gender equity in access to and benefits from energy. World Development Report 2012. Gender Equality and Development Background Paper; 2011.

[10] United Nations. 1987. World Commission on Environment and Development (the Brundtland Commission). Accessed in September 2014 http://www.un.org/documents/ga/res/42/ares42187.htm

[11] Common M, Perrings C. Towards an ecological economics of sustainability. Ecol Econ 1992;6:724.

[12] Solow RM. An almost practical step towards sustainability. Resources for the Future, Washington DC. Resour Policy 1992;19:162-72.

[13] UN Sustainable Energy for All (SE4All) initiative. Accessed in September 2014 at http://www.se4all.org/

[14] Global Alliance for Clean Cookstoves. Accessed in September 2014 http://www.cleancookstoves.org/

[15] SNV World and Hivos People Unlimited. African Biogas Partnership Programme (ABPP), Accessed in September 2014 at http://africabiogas.org/africa-biogas-partnership-programme/

[16] Zhang X, Wang R, Molin H, Martinot E. A study of the role played by renewable energies in China's sustainable energy supply. Energy and Sustainable Development for China 2010;35:4392-9.

[17] SNV World. Domestic Biogas Newsletter 13 February 2013, 8. Accessed in October 2014 at http://www.snvworld.org/en/sectors/renewable-energy/publications?filter= newsletter

[18] Bonjour S, Adair-Rohani H, Wolf J, Bruce NJ, Mehta S, Prüss-Ustün A, Lahiff M, Rehfuess EA, Mishra V, Smith KR. Solid fuel use for household cooking: Country and regional estimates for 1980-2010. Environ Health Persp 2013;121:784-90.

[19] Kumar M, Kumar S, Tyagi SK. Design, development and technological advancement in the biomass cookstoves: A review. Renew Sust Energ Rev 2013;26:265-85.

[20] Brouwer ID, den Hartog AP, Kamwendo MOK, Heldens MWO. Wood quality and wood preferences in relation to food preparation and diet composition in Central Malawi. Ecol Food Nutr 1996;35:1-13.

[21] Omer AM, Fadalla Y. Biogas energy in Sudan. Renew Energ 2003;28:499-507.

[22] Bryceson DF, Howe J. Rural household transport in Africa: Reducing the burden on women? World Dev 1993;21:1715-28.

[23] Biran A, Abbot J, Mace R. Families and firewood: a comparative analysis of the costs and benefits of children in firewood collection and use in two rural communities in Sub-Saharan Africa. Hum Ecol 2004;32:1-25. 
[24] Gordon SB, Bruce NG, Grigg J, Hibberd PL, Kurmi OP, Lam KH, et al. Respiratory risks from household air pollution in low and middle income countries. The Lancet Respiratory Medicine Commission 2014. Accessed in September 2014 at http://dx.doi.org/10.1016/S22132600(14)70168-7

[25] Lim SS, Vos T, Flaxman AD, Danaei G, Shibuya K, Adair-Rohani H, et al. A comparative risk assessment of burden of disease and injury attributable to 67 risk factors and risk factor clusters in 21 regions, 1990-2010: a systematic analysis for the Global Burden of Disease Study 2010. Lancet 2012;380:2224-60.

[26] World Health Organisation. Global Health Observatory (GHO), World Health Statisics 2014. Accessed in October 2014 at http://www.who.int/gho/publications/world_health_statistics/2014/en/

[27] Broadhead J, Bahdon J, Whiteman A. Woodfuel consumption modeling and results. Past trends and future prospects for the utilization of wood for energy. GFPOS/WP/05, global forest products outlook study. Food and Agriculture Organization of the United Nations, Rome 2001.

[28] FAOSTAT. Resources, ResourceSTAT, land. Rome, Italy: Food and Agriculture Organization of the United Nations. Accessed in October 2014 at: http://faostat.fao.org

[29] Arnold M, Köhlin G, Persson R, Shepherd G. Fuelwood revisited: what has changed in the last decade? CIFOR Occasional Paper No. 39. Center for International Forestry Research, Jakarta, Indonesia 2003. Accessed in September 2014 at http://www.cifor.org/publications/pdf_files/OccPapers/OP-39.pdf

[30] Maes WH, Verbist B. Increasing the sustainability of household cooking in developing countries.: Policy implications. Renew Sust Energy Rev 2012;16:4204-21.

[31] Kammen DM, Lew DJ. Review of technologies for the production and use of charcoal. Renewable and appropriate energy laboratory report 2005. Accessed in October 2014 at http://rael.berkeley.edu/sites/default/files/old-site-files/2005/Kammen-Lew-Charcoal-2005.pdf

[32] Akpalu W, Dasmani I, Aglobitse PB. Demand for cooking fuels in a developing country: to what extent do taste and preferences matter? Energ Policy 2011;39:6525-31.

[33] Bruce NG, Rehfuess EA, Smith KR. Household energy solutions in developing countries. In Nriagu, JO, ed. Encyclopedia of Environmental Health. Elsevier, Burlington; 2011 62-74

[34] MacCarty N, Ogle D, Still D, Bond T, Roden C. A laboratory comparison of the global warming impact of five major types of biomass cooking stoves. Energ Sust Dev 2003;12:56-65.

[35] Gwavuya SG, Abele S, Barfuss I, Zeller M, Müller J. Household energy economics in rural Ethiopia: A cost-benefit analysis of biogas energy. Renew Energ 2012;48:202-9.

[36] Mekonnen L. Baseline household and community energy survey in Meskan woreda. F.f. Environment, Editor, Addis Ababa; 2009.

[37] Mudway IS, Duggan ST, Venkataraman C, Habib G, Kelly FJ, Grigg J. Combustion of dried animal dung as biofuel results in the generation of highly redox active fine particulates. Part Fibre Toxicol 2005;2:6.

[38] MacCarty N, Ogle D, Still D, Bond T, Roden C. A laboratory comparison of the global warming impact of five major types of biomass cooking stoves. Energ Sust Dev 2008;XII:56-65.

[39] World Bank. Household cookstove, environment, health and climate change, 2011. Accessed in July 2012 at http://climatechange.worldbank.org/Household\%20Cookstoves-web.pdf

[40] MacCarty N, Still D, Ogle D. Fuel use and emissions performance of fifty cooking stoves in the laboratory and related benchmarks of performance. Energ Sust Dev 2010;14:161-71.

[41] Still D, Kness J. Capturing HEAT Five earth-friendly cooking technologies and how to build them, 2nd ed. Aprovecho Research Center. Accessed in October 2014 at http://weblife.org/capturing_heat/pdf

[42] Baldwin SF. Biomass stoves: engineering design, development and dissemination. Center for Energy and Environmental Studies, Princeton, NJ, 1986, 287.

[43] Roth C. Micro-gasification: cooking with gas from biomass, GIZHERA, 2011. Poverty-oriented Basic Energy Service. Accessed in October 2014 at www.newdawnengineering.com/.../HERA-GIZ\%20micro

[44] Graber ER, Hadas E. Potential energy generation and carbon savings from waste biomass pyrolysis in Israel. Ann Environ Sci 2009;3:207-16.

[45] Torres-Rojas D, Lehmann J, Hobbs P, Joseph S, Neufeldt H. Biomass availability, energy consumption and biochar production in rural households of Western Kenya. Biomass Bioenerg 2011;35:3537-46.

[46] Gaunt JL, Lehmann J. Energy balance and emissions associated with biochar sequestration and yrolysis bioenergy production. Environmental Sci Technol 2008;42:4152-8. 
[47] Wendelbo P, Nielsen PS. Test of pyrolysis gasifier stoves in two institutional" kitchens in Uganda. In Kopetz H, Weber T, Palz W et al., eds. Conference: 10th European Conference and Technology Exhibition on Biomass for Energy and Industry, 08-11 June, Wurzburg, Germany; 1998 1753-6.

[48] International Biochar Initiative. Biochar stoves. 640 Brook Run Dr., Westerville, $\mathrm{OH} 43081$, United States: International Biochar Initiative (Non-profit Organisation). Accessed in January 2012 at http://www.biocharinternational.org/technology/stoves

[49] Reddy SBN. Understanding stoves for environment and humanity. Accessed in October 2014 at http://www.biochar-international.org/sites/default/files/Understanding-Stoves-okt-10webversion.pdf

[50] Openshaw K. Estimating biomass supply: focus on Africa. In: IEA Proceedings Biomass Energy: data, analysis and trends, March 23-24, Paris, IEA/OECD; 1998 241-55.

[51] Atkinson CJ, Fitzgerald JD, Hipps NA. Potential mechanisms for achieving agricultural benefits from biochar application to temperate soils: a review. Plant Soil 2010;337:1-18.

[52] Lehmann J. Bio-energy in the black. Front Ecol Environ 2007;5:381-7.

[53] Whitman T, Lehmann J. Biochar - One way forward for soil carbon in offset mechanisms in Africa? Environ Sci Policy 2009;12:1024-7.

[54] Mata-Alvarez J, Macé S, Llabrés P. Anaerobic digestion of organic solid wastes. An overview of research achievements and perspectives. Bioresource Technol 2000;74:3-16.

[55] Dimpl E. Small-scale Electricity Generation from Biomass. Part II: Biogas. Deutsche Gesellschaft für Technische Zusammenarbeit (GTZ)-HERA; 2010.

[56] Zielonka S, Lemmer A, Oechsner H, Jungbluth T. Energy balance of a two-phase anaerobic digestion process for energy crops. Eng Life Sci 2010;10:515-9.

[57] Singh KJ, Sooch S. Comparative study of economics of different models of family size biogas plants for state of Punjab, India. Energ Conserv Manage 2004;45:1329-41.

[58] Semple S, Apsley A, Wushishu A, Smith J. Commentary: Switching to biogas - What effect could it have on indoor air quality and human health? Biomass and Bioenergy 2014;70:125-9.

[59] Buswell AM, Mueller HF. Mechanism of methane fermentation. Ind Eng Chem Res 1952, 44:5502.

[60] Pandey B, Subedi PS, Sengendo M, Monroe I. Biogas for better life: an African initiative Report on the feasibility for a National Household Biogas Commercialization Program in Uganda. The Hague, The Netherlands: SNV (Prepared by Winrock International); 2007. Accessed in October 2014 at http://www.snvworld.org/en/Documents/Biogas_for_better_life_an_African_initiative_Feasibilit y_study_Uganda_2007.pdf

[61] Gutser R, Ebertseder T, Weber A, Schraml M, Schmidhalter U. Short-term and residual availability of nitrogen after long term application of organic fertilizers on arable land. J Plant Nutr Soil Sc 2005;168:439-46.

[62] Sänger A, Geisseler D, Ludwig B. C and N dynamics of a range of biogas slurries as a function of application rate and soil texture: a laboratory experiment. Arch Acker Pfl Boden 2014;60:1779-94.

[63] Bond T, Templeton MR. History and future of domestic biogas plants in the developing world. Energ Sust Dev 2011;15:347-54.

[64] Henao J, Baanante C. Agricultural production and soil nutrient mining in Africa: Implications for resource conservation and policy development. IFDC Technical Bulletin. International Fertilizer Development Center, Muscle Shoals, AL, USA; 200675.

[65] De Ridder N, van Keulen H. Some aspects of the role of organic matter in sustainable intensified arable farming systems in the West-African semi-arid tropics (SAT). Fert Res1990;26:299310.

[66] Mueller-Harvey I, Juo ASR, Wild A. Soil Organic C, N, S and P after clearance in Nigeria: Mineralization rates and spatial variability. J Soil Sci 1985;36:585-91.

[67] Kadyampakeni DM. Soil, water, and nutrient management options for climate change adaptation in Southern Africa. Agron J 2014;106:100-10.

[68] Kamau M, Smale M, Mutua M. Farmer demand for soil fertility management practices in Kenya's grain basket. Food Security 2014;6:793-806.

[69] Omotayo OE, Chukwuka S. Soil fertility restoration techniques in sub-Saharan Africa using organic resources. Afr J Agric Sci 2009;4:144-50.

[70] Vanlauwe B, Giller KE. Popular myths around soil fertility management in sub-Saharan Africa. Agr Ecosyst Environ 2006;116:34-46. 
[71] Chikowo R, Zingore S, Snapp S, Johnston A. Farm typologies, soil fertility variability and nutrient management in smallholder farming in Sub-Saharan Africa. Nutr Cycl Agroecosys 2014;100:1-18.

[72] Catt JA, Howse KR, Christian DG, Lane PW, Harris GL, Goss MJ. Strategies to decrease nitrate leaching in the Brimstone farm experiment, Oxfordshire, UK, 1988-93: the effect of straw incorporation. J Agr Sci 1998;131:309-19.

[73] Clasen TF, Bostoen K, Schmidt WP, Boisson S, Fung ICH, Jenkins MW, Scott B, Sugden S, Cairncross S. Interventions to improve excreta disposal for preventing diarrhea. The Cochrane Library 2007, 1. Accessed in October 2014 at http://dx.doi.org/10.1002/14651858.CD007180.

[74] Hutchison ML, Walters LD, Avery SM, Synge BA, Moore A. Levels of zoonotic agents in British livestock manures. Lett Appl Microbiol 2004;39:207-14.

[75] Gagliardi JV, Karns JS. Leaching of Escherichia coli O157:H7 in diverse soils under various agricultural management practices. App Environ Microbiol 2000;66:877-83.

[76] Jamieson RC, Gordon RJ, Sharples KE, Stratton GW, Madani A. Movement and persistence of fecal bacteria in agricultural soils and subsurface drainage water: a review. Can Biosys Eng 2002;44:1-9.

[77] Avery LM, Booth P, Campbell C, Tompkins D, Hough RL. Prevalence and survival of potential pathogens in source segregated green waste compost. Sci Tot Environ 2012;431:128-38.

[78] Wichuk KM, McCartney D. A review of the effectiveness of current time-temperature regulations on pathogen inactivation during composting. J Environ Eng Sci 2007;6:573-86.

[79] Bernal MP, Sanchez-Monedero MA, Paredes C, Roig A. Carbon mineralization from organic wastes at different composting stages during their incubation with soil. Agric Ecosyst Environ 1998;69:175-89.

[80] Kirchmann H, Widén P. Separately collected organic household wastes: chemical composition and composting characteristics. Swed J Agric Res 1994, 24, 3-12.

[81] Lekasi JK, Tanner JC, Kimani SK, Harris PJC. Manure management methods to enhance nutrient quantity and quality on smallholdings in the Central Kenya Highlands. Biol Agric Hortic 2002;19:315-32.

[82] Möller K, Müller T. Effects of anaerobic digestion on digestate nutrient availability and crop growth: a review. Eng Life Sci 2012;12:242-57.

[83] Schievano A, D'Imporzano G, Salati S, Adani F. On-field study of anaerobic digestion full-scale plants (part I): an on-field methodology to determine mass, carbon and nutrients balance. Bioresour Technol 2011;102:7737-44.

[84] Jewitt S. Poo gurus? Researching the threats and opportunities presented by human waste. Appl Geog 2011;31:761-9.

[85] Makni $\mathrm{H}$. Disinfection of secondary effluents by infiltration percolation. Wa Sci Technol 2001;43:175-8.

[86] Diener S, Semiyaga S, Niwagaba CB, Muspratt AM, Gning JB, Mbéguéré $M$, et al. A value proposition: Resource recovery from faecal sludge - Can it be the driver for improved sanitation? Resour Conserv Recy 2014;88:32-8.

[87] Okon PB, Ogeh JS, Amalu UC. Effect of rice husk ash and phosphorus on some properties of acid sands and yield of okra. Commun Soil Sci Plan 2005;36:833-45.

[88] Wendt JW. Groundnut response to ash, phosphorus, lime and tillage in southern Cameroon. Biol Agric Hortic 2002;20:187-99.

[89] Vanlauwe B. Organic matter availability and management in the context of integrated soil fertility management in sub-Saharan Africa. In Hester, RE, Harrison, RM, eds. Soils and Food Security. Issues in Environmental Science and Technology Series. Royal Society of Chemistry, Cambridge; 2012 135-157.

[90] Van Reuler H, Janssen BH. Comparison of the fertilizing effects of ash from burnt secondary vegetation and of mineral fertilizers on upland rice in south-west Cote d'Ivoire. Fert Res 1995;45:1-11.

[91] Materechera SA, Mkhabela TS. The effectiveness of lime, chicken manure and leaf litter ash in ameliorating acidity in a soil previously under black wattle (Acacia mearnsii) plantation. Bioresource Technol 2002;85:9-16.

[92] Novak JM, Spokas KA, Cantrell KB, Ro KS, Watts DW, Glaz B, et al. Effects of biochars and hydrochars produced from lignocelluosic and animal manure on fertility of a Mollisol and Entisol. Soil Use Manage 2014;30:175-81.

[93] Phillipshoward KD, Lyon F. Agricultural intensification and the threat to soil fertility in Africa Evidence from the Jos Plateau, Nigeria. Geogr J 1994;160:252-65. 
[94] ISRIC - World Soil Information. Soil property maps of Africa at $1 \mathrm{~km}$. Accessed in October 2014 at www.isric.org

[95] Kloss S, Zehetner F, Dellantonio A, Hamid R, Ottner F, Liedtke V, et al. Characterization of Slow Pyrolysis Biochars: Effects of Feedstocks and Pyrolysis Temperature on Biochar Properties. Journal Environ Qual 2012;41:990-1000.

[96] Rovira P, Duguy B, Vallejo VR. Black carbon in wildfire-affected shrubland Mediterranean soils. J Plant Nutr Soil Sc 2009;172:43-52.

[97] Liang B, Lehmann J, Solomon D, Kinyangia J, Grossman J, O'Neill B, et al. Black carbon increases cation exchange capacity in soils. Soil Sci Soc Am J 2006;70:1719-30.

[98] Bruun EW, Hauggaard-Nielsen H, Ibrahim N, Egsgaard H, Ambus P, Jensen PA, et al. Influence of fast pyrolysis temperature on biochar labile fraction and short-term carbon loss in a loamy soil. Biomass Bioenerg 2011;35:1182-9.

[99] Nguyen BT, Lehmann J, Kinyangi J, Smernik R, Riha SJ, Engelhard MH. Long-term black carbon dynamics in cultivated soil. Biogeochemistry 2009;92:163-76.

[100] Lehmann J, Rondon MA. Bio-char soil management on highly weathered soil in the humid tropics. Chapter 36. In Uphoff, N, ed. Biological approaches to sustainable soil systems. CRC , Boca Raton; 2005 517-530.

[101] Esrey SA, Feachem R, Hughes JM. Interventions for the control of diarrhoeal diseases among young children: improving water supplies and excreta disposal facilities. B World Health Organ 1985;63:757-72.

[102] Yongabi KA, Harris PL, Lewis DM. Poultry faeces management with a simple low cost plastic digester. Afr J Biotechnol 2009;8:1560-6.

[103] Tumwine JK, Thompson J, Katui-Katua M, Mujwahuzi M, Johnstone N, Porras I. Sanitation and hygiene in urban and rural households in East Africa. Int J Environ Heal R 2014;13:107-15.

[104] Nyenje PM, Havik JCN, Foppen JW, Muwanga A, Kulabako R. Understanding the fate of sanitation-related nutrients in a shallow sandy aquifer below an urban slum area. J Contam Hydrol 2014;164:259-74.

[105] Esrey SA. Water, waste, and well-being: A multicountry study. Am J Epidemiol 1996;143:60823.

[106] Madungwe E, Sakuringwa S. Greywater reuse: A strategy for water demand management in Harare? Phys Chem Earth 2007;32:15-8.

[107] Keraita B, Konradsen F, Drechsel P, Abaidoo RC. Reducing microbial contamination on wastewater-irrigated lettuce by cessation of irrigation before harvesting. Trop Med Int Heal 2007;12:8-14.

[108] Wriege-Bechtold A, Peter-Froehlich A, Barjenbruch M. Alternative sanitary concepts for rural and urban areas. In Brebbia CA, Neophytou M, Beriatos E, loannou I, Kungolos AG, eds. Sustainable Development and Planning iv, Vols 1 and 2. WIT Transactions on Ecology and the Environment, Ashton, Southampton; 2009 995-1005.

[109] Hallett PD, Loades KW, Krümmelbein J. Soil physical degradation: threats and opportunities to food security. In Hester RE, Harrison RM, eds. Soils and Food Security, Issues in Environmental Science and Technology. Roy Soc Ch 2012;198-226.

[110] Leu JM, Traore S, Wang Y-M, Kan C-E. The effect of organic matter amendment on soil water holding capacity change for irrigation water saving: Case study in Sahelian environment of Africa. Sci Res Essays 2010;5:3564-71.

[111] Hardie M, Clothier B, Bound S, Oliver G, Close D. Does biochar influence soil physical properties and soil water availability? Plant Soil 2014;376:347-61.

[112] Zaongo CGL, Wendt CW, Lascano RJ, Juo ASR. Interactions of water, mulch and nitrogen on sorghum in Niger. Plant Soil 1997;197:119-26.

[113] Stroosnijder L. Modifying land management in order to improve efficiency of rainwater use in the African highlands. Soil Till Res 2009;103:247-56.

[114] Brouder SM, Gomez-Macpherson H. The impact of conservation agriculture on smallholder agricultural yields: A scoping review of the evidence. Agr Ecosyst Environ 2014;187:11-32.

[115] Adamtey N, Coffie O, Ofusu-Budu KG, Ofusu-Anim J, Laryea KB, Forster D. Effect of Nenriched co-compost on transpiration efficiency and water-use efficiency of maize (Zea mays L.) under controlled irrigation. Agr Water Manage 2010;97:995-1005.

[116] Landi M, Sovacool BK, Eidsness J. Cooking with gas: policy lessons from Rwanda's National Domestic Biogas Program (NDBP). Energy Sust Develop 2013;17:347-56.

[117] van Nes WJ. Asia hits the gas - Biogas from anaerobic digestion rolls out across Asia. Renew Energ World, 2006;Jan-Feb:102-4. Accessed 11/02/15 at http://www.search4dev.nl/record/283894. 
[118] Jeuland MA, Pattanayak SK. Benefits and costs of improved cookstoves: assessing the implications of variability in health, forest and climate impacts. PLoS ONE 2012;7:30338. doi:10.1371/journal.pone.0030338

[119] Bedi AS, Pellegrinia L, Tasciottia L. Impact evaluation of Netherlands supported programmes in the area of Energy and Development Cooperation in Rwanda Impact Evaluation of Rwanda's National Domestic Biogas Programme International Institute of Social Studies, Erasmus University Rotterdam, The Netherlands, 2013. Accessed in October 2014 at http://www.iobevaluatie.nl/sites/iobevaluatie.nl/files/Impact\%20Evaluation\%20of\%20Rwanda's\%20National \%20Domestic\%20Biogas\%20Programme.pdf

[120] Walekhwa PN, Drake L, Mugisha J. Economic viability of biogas energy production from family sized digesters in Uganda. Biomass Bioenerg 2014;70:26-39.

[121] Renwick MP, Subedi S, Hutton G. Biogas for Better Life: An African Initiative A Cost-Benefit Analysis Of National And Regional Integrated Biogas And Sanitation Programs. In SubSaharan Africa Draft Final Report Prepared For The Dutch Ministry Of Foreign Affairs April 2007. Winrock International; 2007. Accessed in October 2014 at http://www.susana.org/en/resources/library/details/596

[122] Smith J, Apsley A, Avery L, Baggs E, Balana B, Bechtel K, et al. The potential of small-scale biogas digesters to improve livelihoods and long term sustainability of ecosystem services in Sub-Saharan Africa, 2013. Accessed in October 2014 at http://r4d.dfid.gov.uk/Output/193337/Default.aspx

[123] Ding W, Niu H, Chen J, Du J, Wu Y. Influence of household biogas digester use on household energy consumption in a semi-arid rural region of northwest China. Appl Energ 2012;97:1623.

[124] Huba E, Paul E. National Domestic Biogas Programme Rwanda: Baseline Study Report. Ministry of Infrastructure, Kigali, Rwanda, SNV and GTZ. Accessed in October 2014 at http://www.snvworld.org/fr/publications/baseline-study-national-domestic-biogas-programme

[125] Pachauri S, Brew-Hammond A, Barnes DF, Bouille DH, Gitonga S, Modi V, et al. Energy access for development Chapter 19. In Global Energy Assessment: Toward a Sustainable Future, Cambridge University Press and IIASA; 2012 1401-1458.

[127] Parawira W. Biogas technology in sub-Saharan Africa: status, prospects and constraints. Rev Environ Sci Biotechnol 2009;8:187-200.

[128] Walekhwa PN, Mugisha J, Drake L. Biogas energy from family-sized digesters in Uganda: Critical factors and policy implications. Energ Policy 2009;37:2754-62.

[129] Neij L (2008) Cost development of future technologies for power generation - A study based on experience curves and complementary bottom-up assessments. Energ Policy 2008;36:220011.

[130] Rota A, Sehgal K. FlexiBiogas - a climate change adaptation and mitigation technology. International Fund for Agricultural Development, Rome, Italy: IFAD Rural; 2014, p. 21.

[131] Amigun B, Sigamoney R, von Blottnitz $H$. Commercialisation of biofuel industry in Africa: A review. Renew Sustain Energy Rev 2008;12:690-711.

[132] Glemarec Y. Financing off-grid sustainable energy access for the poor. Energy Policy 2012;47:87-93.

[133] Lewis JL, Pattanayak SK. Who Adopts Improved Fuels and Cookstoves? A Systematic Review. Environ Health Persp 2012;120:637-45.

[134] Jian L. Socioeconomic barriers to biogas development in rural Southwest China: an ethnographic case study. Hum Organ 2009;68:415-30.

[135] Dingqiang S, Junfei B, Huanguang Q, Yaqing C. Impact of government subsidies on household biogas use in rural China. Energ Policy 2014;73:748-56.

[136] Köhlin G, Sills EO, Pattanayak SK, Wilfong C. Energy, gender and development - what are the linkages? Where is the evidence? The World Bank Sustainable Development Network Social Development Unit, September 2011. Background Paper to the 2012 World Development Report, WPS5800; 2011.

[137] Mupawaenda AC, Chawatama S, Muvavarirwa P. Gender issues in livestock production: a case study of Zimbabwe. Trop Anim Health Pro 2009;41:1017-21.

[138] Doss C. Intrahousehold bargaining and resource allocation in developing countries. World Bank Res Obser 2013;28:52-78.

[139] Pachauri S, Rao ND. Gender impacts and determinants of energy poverty: are we asking the right questions? Curr Opin Environ Sust 2013;5:205-15.

[140] Nyoni S. Women and energy: Lessons from the Zimbabwe Experience. Working paper 22. Harare: Zimbabwe Environment Research Organisation (ZERO); 1993. 
[141] Mu R, van de Walle D. Left behind to farm? Women's labor re-allocation in rural China. Labour Econ 2011;18:S83-S97.

[142] Ramani KV, Heijndermans E. Energy, poverty and gender. Synthesis Report. World Bank. April 2003.

[143] Koolwal G, van de Walle D. Access to water, women's work, and child outcomes. Econ Dev Cult Change 2013;61:369-405.

[144] Ray I. Women, water, and development. Annu Rev Env Resour 2007;32:421-49.

[145] Troncoso K, Castillo A, Merino L, Lazos E, Masera OR. Understanding an improved cookstove program in rural Mexico: An analysis from the implementers' perspective. Energ Policy 2011;39:7600-08.

[146] Barnes DF, Openshaw K, Smith KR, van der Plas R. What makes people cook with improved biomass stoves? A comparative international review of stove programs. World Ban T 1994;242.

[147] Waylen K, Fischer A, McGowan P, Thirgood S, Milner-Gulland EJ. The effect of local cultural context on the success of community-based conservation interventions. Conserv Biol 2010;24:1119-24.

[148] Chambers R. Whose reality counts? Putting the first last. Intermediate Technology Publications, London, 1997.

[149] Hajer MA. Doing discourse analysis: coalitions, practices, meaning. In Van den Brink M, Metze $\mathrm{T}$, eds. Words matter in policy and planning: discourse theory and method in the social sciences. NGSURR, Utrecht, 2006 65-74.

[150] Fischer A, Marshall K. Framing the landscape: Discourses of woodland restoration and moorland management in Scotland. J Rural Stud 2010;26:185-93.

[151] Fischer A, Kereži V, Arroyo B, Delibes-Mateos M, Tadie D, Lowassa A, et al. (De)legitimising hunting - discourses over the morality of hunting in Europe and eastern Africa. Land Use Policy 2013;32:261-270.

[152] Adger WN, Benjaminsen TA, Brown K, Svarstad H. Advancing a political ecology of global environmental discourses. Dev Change 2001;32:681-715.

[153] Svarstad H, Petersen LK, Rothman D, Siepel H, Wätzold F. Discursive biases of the environmental research framework DPSIR. Land Use Policy 2008:25;116-25.

[154] Roe EM. Except-Africa: Postscript to a special section on development narratives. World Dev 1995;23:1065-9.

[155] Benjaminsen TA, Svarstad H. The death of an elephant: Conservation discourses versus practices in Africa. Forum Dev Stud 2010;37:385-408.

[156] O'Reilly K. "Traditional" women, "modern" water: Linking gender and commodification in Rajasthan, India. Geoforum 2006;37:958-72.

[157] Armeddariz B, Morduch J. The Economics of Microfinance. MIT Press, Cambridge Massachusetts, 2005. 
Figure 1

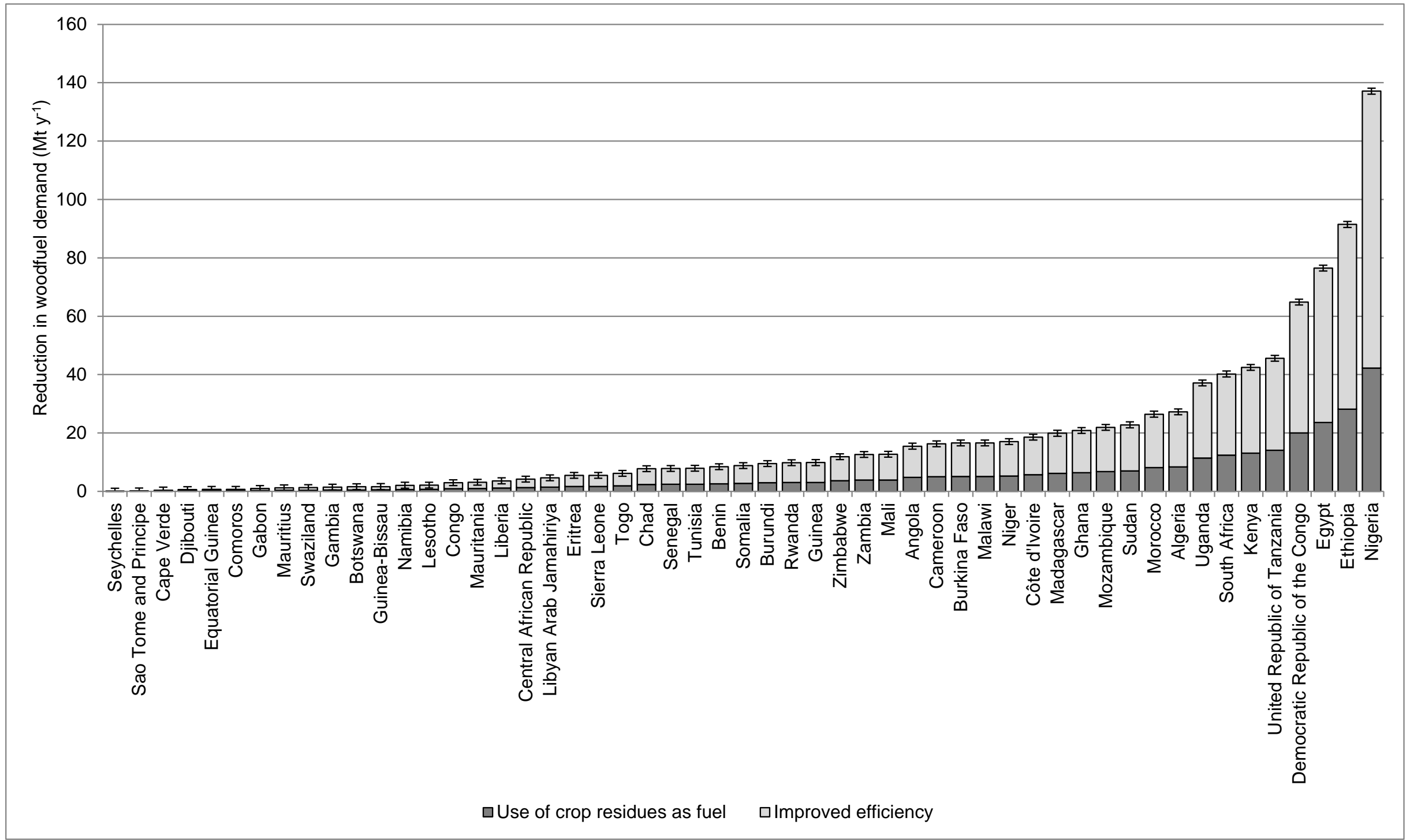


Figure 2

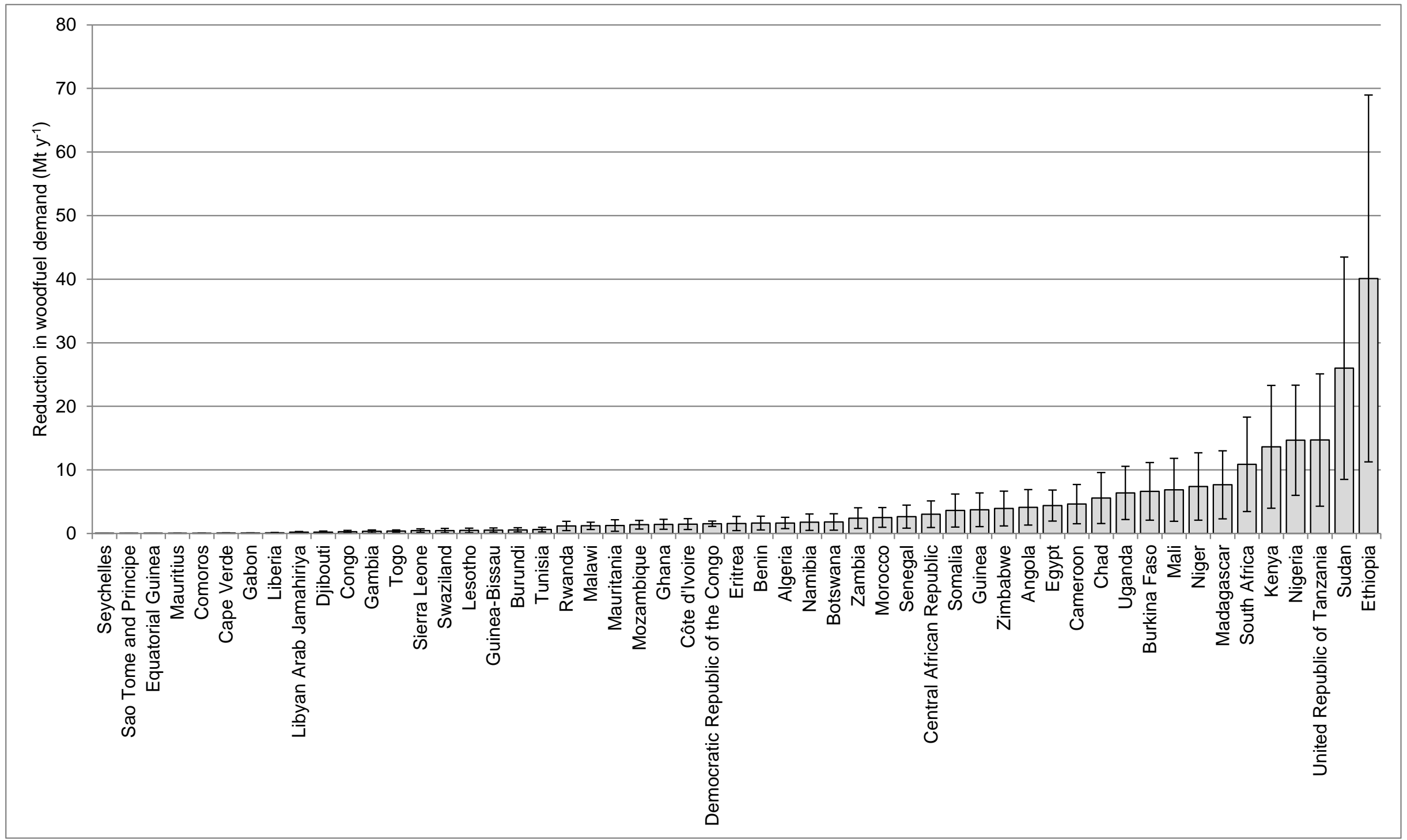


Figure 3

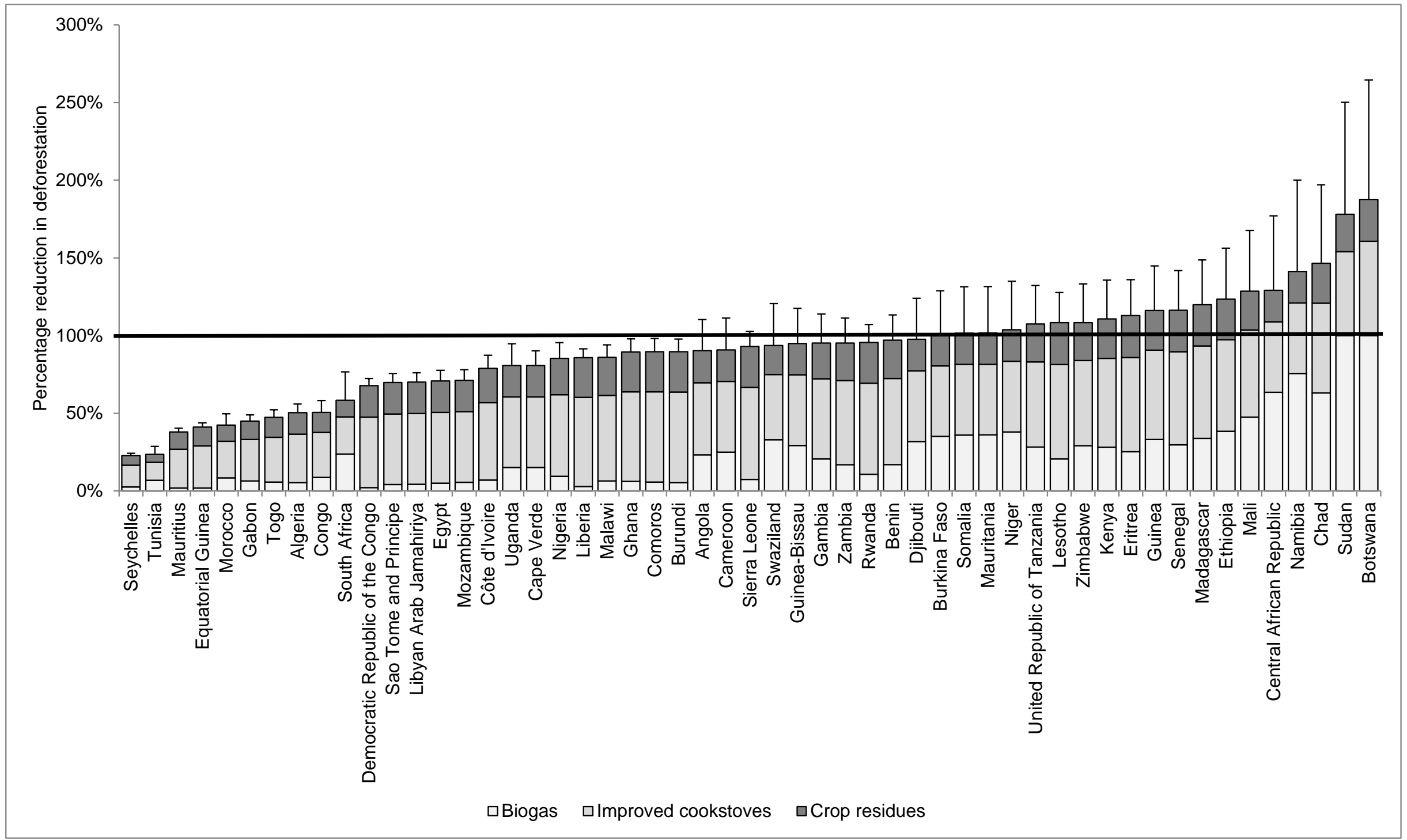


Figure 4

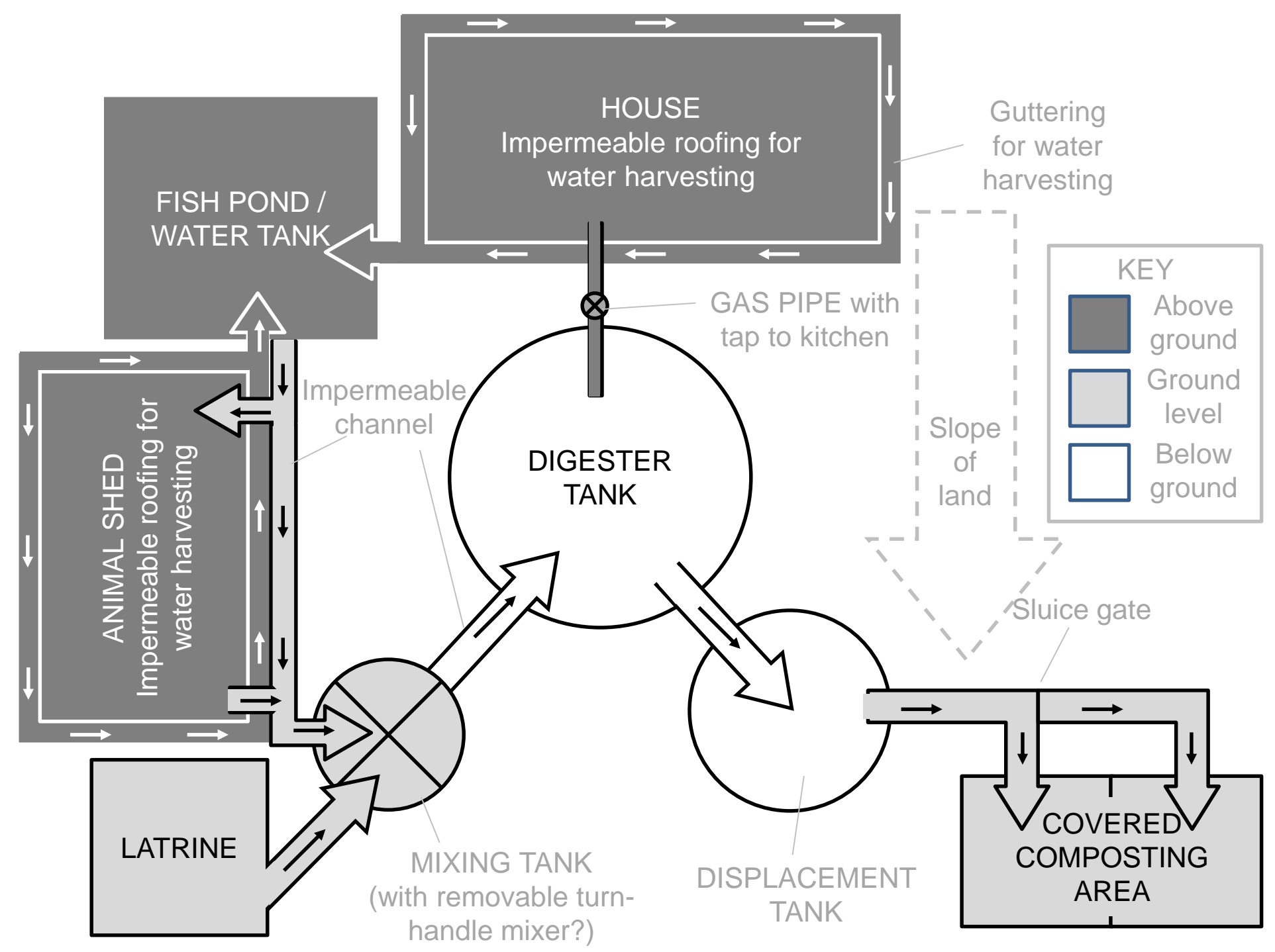


Tables

Table 1. Use of organic wastes for energy provision

Table 2. Use of organic wastes for food provision

Table 3. Use of organic wastes for water provision 
Table 1. Use of organic wastes for energy provision

\begin{tabular}{|c|c|c|c|c|c|c|c|c|c|}
\hline \multirow{2}{*}{$\begin{array}{c}\text { Practice } \\
\text { Fuel source }\end{array}$} & & \multicolumn{3}{|c|}{ Burning } & \multicolumn{2}{|c|}{ Pyrolysis } & \multicolumn{3}{|c|}{ Anaerobic digestion } \\
\hline & & Charcoal & Wood & Dung & Wood & $\begin{array}{l}\text { Dry crop- } \\
\text { residues }\end{array}$ & Animal dung & $\begin{array}{l}\text { Human } \\
\text { excreta }\end{array}$ & $\begin{array}{l}\text { Food and } \\
\text { crop-residues }\end{array}$ \\
\hline \multirow[t]{5}{*}{ Advantages } & Equipment & \multicolumn{3}{|c|}{$\begin{array}{c}\text { Traditional method uses existing recipes \& } \\
\text { equipment }\end{array}$} & & & & & \\
\hline & Energy source & & & & $\begin{array}{l}\text { Efficient use of } \\
\text { energy - } \\
\text { reduces } \\
\text { deforestation? }\end{array}$ & $\begin{array}{l}\text { Additional } \\
\text { energy source }\end{array}$ & & $\begin{array}{l}\text { Allows use of } \\
\text { additional } \\
\text { organic } \\
\text { materials }\end{array}$ & \\
\hline & \multirow{2}{*}{ Cooking } & \multirow{2}{*}{\multicolumn{3}{|c|}{ Preferred flavour of food }} & \multicolumn{2}{|c|}{ Low emission of particulates } & \multicolumn{3}{|c|}{ Low emission of particulates } \\
\hline & & & & & \multicolumn{2}{|c|}{ Rapid cooking method } & \multicolumn{3}{|c|}{ Rapid cooking method } \\
\hline & Lighting & & & & & & \multicolumn{3}{|c|}{ Provides lighting } \\
\hline \multirow{4}{*}{ Disadvantages } & Cost & \multicolumn{3}{|c|}{ Cost of fuel purchase } & \multicolumn{2}{|c|}{$\begin{array}{c}\text { New method - needs new } \\
\text { equipment - not widely available - } \\
\text { elevated cost }\end{array}$} & \multicolumn{3}{|c|}{ High cost of digester and additional equipment } \\
\hline & Labour & \multicolumn{2}{|c|}{$\begin{array}{l}\text { Deforestation - increased time } \\
\quad \text { for wood collection }\end{array}$} & $\begin{array}{l}\text { Labour to dry } \\
\text { dung }\end{array}$ & $\begin{array}{l}\text { Deforestation - } \\
\text { increased time } \\
\text { for wood } \\
\text { collection }\end{array}$ & & \multicolumn{3}{|c|}{ Requires additional labour to feed digester } \\
\hline & Water & & & & & & \multicolumn{3}{|c|}{ Requires additional water } \\
\hline & Cooking & & \multicolumn{2}{|c|}{$\begin{array}{l}\text { High particulate and } \mathrm{CO} \\
\text { emissions }\end{array}$} & \multicolumn{2}{|c|}{$\begin{array}{l}\text { Very hot flame - requires different } \\
\text { cooking approach }\end{array}$} & \multicolumn{3}{|c|}{$\begin{array}{c}\text { Best suited to quick cooking - may require change } \\
\text { of techniques, recipes or equipment }\end{array}$} \\
\hline
\end{tabular}


Table 2. Use of organic wastes for food provision

\begin{tabular}{|c|c|c|c|c|c|c|c|}
\hline \multirow{2}{*}{$\begin{array}{c}\text { Practice } \\
\begin{array}{c}\text { Source of } \\
\text { material }\end{array}\end{array}$} & & \multirow{2}{*}{$\begin{array}{c}\text { Apply fresh wastes } \\
\begin{array}{c}\text { Farmyard manure \& } \\
\text { slurry }\end{array}\end{array}$} & \multirow{2}{*}{$\begin{array}{c}\text { Apply compost } \\
\begin{array}{c}\text { Farmyard manure, food } \\
\text { wastes and crop- } \\
\text { residues }\end{array} \\
\end{array}$} & \multicolumn{2}{|l|}{ Apply bioslurry } & \multicolumn{2}{|c|}{ Apply biochar } \\
\hline & & & & $\begin{array}{l}\text { Farmyard manure, slurry, food } \\
\text { wastes \& crop-residues }\end{array}$ & $\begin{array}{l}\text { Human } \\
\text { excreta }\end{array}$ & Wood & $\begin{array}{l}\text { Dry crop- } \\
\text { residues }\end{array}$ \\
\hline \multirow{3}{*}{ Advantages } & \multirow{2}{*}{$\begin{array}{l}\text { Nutrients } \\
\text { and } \\
\text { Carbon }\end{array}$} & \multirow[b]{2}{*}{$\begin{array}{l}\text { No loss of nutrients } \\
\text { during treatment }\end{array}$} & \multirow{2}{*}{$\begin{array}{l}\text { Homogeneous material } \\
\text { that will release nutrients } \\
\text { as needed by the crop }\end{array}$} & \multicolumn{2}{|c|}{$\begin{array}{l}\text { Good source of nutrients for crop - nutrients in } \\
\text { available form and losses during treatment are low }\end{array}$} & \multicolumn{2}{|c|}{$\begin{array}{c}\text { Contains recalcitrant carbon so } \\
\text { increases carbon sequestration } \\
\text { in soil }\end{array}$} \\
\hline & & & & & $\begin{array}{l}\text { Additional } \\
\text { carbon and } \\
\text { nutrients }\end{array}$ & \multicolumn{2}{|c|}{$\begin{array}{l}\text { High surface area and cation } \\
\text { exchange capacity can reduce } \\
\text { nutrient loss and increase } \\
\text { carbon in micro-organisms }\end{array}$} \\
\hline & Pathogens & & Some reduction & \multicolumn{2}{|c|}{ Reduction of aerobic pathogens } & \multicolumn{2}{|c|}{ Reduction of most pathogens } \\
\hline \multirow{7}{*}{ Disadvantages } & & Heterogeneous & & \multirow{2}{*}{\multicolumn{2}{|c|}{ Carbon is lost during treatment }} & \multicolumn{2}{|c|}{$\begin{array}{l}\text { High proportion of nutrients are } \\
\text { lost during treatment }\end{array}$} \\
\hline & $\begin{array}{l}\text { Nutrients } \\
\text { and carbon }\end{array}$ & $\begin{array}{c}\text { material - locking up } \\
\text { and loss of nutrients in } \\
\text { soil }\end{array}$ & $\begin{array}{l}\text { Carbon and nutrients are } \\
\text { lost during treatment }\end{array}$ & & & $\begin{array}{l}\text { Increased } \\
\text { wood use }\end{array}$ & $\begin{array}{l}\text { Crop-residues } \\
\text { could be fed to } \\
\text { animals }\end{array}$ \\
\hline & Pathogens & Spread of pathogens & Some pathogens remain & \multicolumn{2}{|c|}{ Anaerobic pathogens remain } & & \\
\hline & Cost & & & \multicolumn{2}{|l|}{ High cost of equipment } & \multicolumn{2}{|c|}{$\begin{array}{l}\text { Equipment not widely available - } \\
\text { higher cost }\end{array}$} \\
\hline & Labour & & Labour to make compost & \multicolumn{2}{|c|}{ Labour to feed the digester } & & \\
\hline & $\begin{array}{l}\text { Resource } \\
\text { use }\end{array}$ & & & & & $\begin{array}{l}\text { Increased } \\
\text { wood use }\end{array}$ & $\begin{array}{l}\text { Crop-residues } \\
\text { could be fed to } \\
\text { animals }\end{array}$ \\
\hline & Water & & & \multicolumn{2}{|c|}{ Requires additional water to mix into a slurry } & \multicolumn{2}{|c|}{ Cannot use wet wastes } \\
\hline
\end{tabular}


Table 3. Use of organic wastes for water provision

\begin{tabular}{|c|c|c|c|c|c|c|c|c|c|}
\hline \multirow{2}{*}{$\begin{array}{c}\text { Practice } \\
\text { Type }\end{array}$} & & \multicolumn{4}{|c|}{$\begin{array}{l}\text { Treat organic wastes to reduce pathogens before releasing to } \\
\text { the environment }\end{array}$} & \multicolumn{4}{|c|}{$\begin{array}{l}\text { Apply organic waste to the soil to increase water holding } \\
\text { capacity and reduce need for irrigation }\end{array}$} \\
\hline & & Burning & Pyrolysis & Composting & $\begin{array}{l}\text { Anaerobic } \\
\text { digestion }\end{array}$ & Fresh waste & Compost & Bioslurry & Biochar \\
\hline \multirow{4}{*}{ Advantages } & $\begin{array}{l}\text { Spread of } \\
\text { disease }\end{array}$ & \multicolumn{2}{|c|}{$\begin{array}{l}\text { Complete treatment of } \\
\text { pathogens }\end{array}$} & $\begin{array}{l}\text { Treatment of } \\
\text { some } \\
\text { pathogens }\end{array}$ & $\begin{array}{l}\text { Treatment of } \\
\text { aerobic } \\
\text { pathogens }\end{array}$ & $\begin{array}{l}\text { Quick disposal } \\
\text { (reduces flies) }\end{array}$ & $\begin{array}{l}\text { Reduces some } \\
\text { pathogens }\end{array}$ & $\begin{array}{l}\text { Reduces } \\
\text { aerobic } \\
\text { pathogens }\end{array}$ & $\begin{array}{l}\text { Reduces most } \\
\text { pathogens }\end{array}$ \\
\hline & Labour & \multicolumn{2}{|c|}{$\begin{array}{l}\text { Easy treatment process. } \\
\text { Reduces volume }\end{array}$} & & & & & \multicolumn{2}{|c|}{$\begin{array}{l}\text { Reduced volume of waste } \\
\text { materials }\end{array}$} \\
\hline & Cost & $\begin{array}{l}\text { No additional } \\
\text { equipment }\end{array}$ & & $\begin{array}{l}\text { No additional } \\
\text { equipment }\end{array}$ & & & & & \\
\hline & Water use & \multicolumn{2}{|c|}{ Dry materials } & No extra water & & \multicolumn{4}{|c|}{ Increases water holding capacity } \\
\hline \multirow{4}{*}{ Disadvantages } & $\begin{array}{l}\text { Spread of } \\
\text { disease }\end{array}$ & & & \multicolumn{2}{|c|}{$\begin{array}{l}\text { Some pathogens may remain in } \\
\text { treated waste }\end{array}$} & $\begin{array}{l}\text { High pathogen } \\
\text { content }\end{array}$ & $\begin{array}{c}\text { Some } \\
\text { pathogens } \\
\text { remain in } \\
\text { waste } \\
\end{array}$ & $\begin{array}{c}\text { Anaerobic } \\
\text { pathogens } \\
\text { may remain }\end{array}$ & \\
\hline & Labour & & & \multicolumn{2}{|c|}{$\begin{array}{l}\text { Requires additional labour for } \\
\text { treatment process }\end{array}$} & \multicolumn{2}{|c|}{$\begin{array}{l}\text { Transport of high volume } \\
\text { materials to the fields }\end{array}$} & & \\
\hline & Cost & & $\begin{array}{c}\text { Additional } \\
\text { equipment } \\
\text { needed }\end{array}$ & & $\begin{array}{l}\text { Additional } \\
\text { expensive } \\
\text { equipment }\end{array}$ & & & & \\
\hline & Water use & & & & $\begin{array}{l}\text { Requires } \\
\text { additional } \\
\text { water }\end{array}$ & & & & \\
\hline
\end{tabular}


